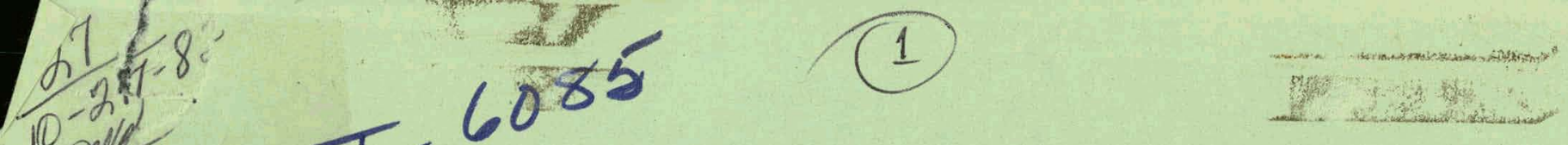

UCID- 19580

\title{
ANALYZE USERS' GUIDE
}

Steve Azevedo

October 1982

This is an informal report intended primarily for internal or limited external distribution. The apinions and conclusions stated are those of the author and may or may not be those of the Laboratury.

Work performal under the auspices ot the U.S. Department of Energy by the Lawience Livermore Laboratory under ( ontract W-7405-Lng 18. 


\section{DISCLAIMER}

This report was prepared as an account of work sponsored by an agency of the United States Government. Neither the United States Government nor any agency Thereof, nor any of their employees, makes any warranty, express or implied, or assumes any legal liability or responsibility for the accuracy, completeness, or usefulness of any information, apparatus, product, or process disclosed, or represents that its use would not infringe privately owned rights. Reference herein to any specific commercial product, process, or service by trade name, trademark, manufacturer, or otherwise does not necessarily constitute or imply its endorsement, recommendation, or favoring by the United States Government or any agency thereof. The views and opinions of authors expressed herein do not necessarily state or reflect those of the United States Government or any agency thereof. 


\section{DISCLAIMER}

Portions of this document may be illegible in electronic image products. Images are produced from the best available original document. 


\section{MASTER}

ANALYZE USERS' GUIDE

Steve Azevedo

This report is a reproduction of the visuals that were used in the "ANALYZE Users' Guide" lectures of the videotaped LLNL Continuing Education Course CE2018-H, State Space Lectures. The course was given in Spring 1982 through the EE Department Education office.

Since ANALYZE is menu-driven, interactive, and has self-explanatory questions (sort of), these visuals and the two 50-minute videotapes are the only documentation which comes with the code. More information about the algorithms contained in ANALYZ can be obtained from the IEEE book on Programs for Digital Signal Processing (IEEE Press, Edited by the DSP Committee of IEEE-ASSP Society, John Wiley and Sons, New York, N.Y., 1979).

\section{MOTIGE}

PORTIBRS OF THS REPORT ARE HLEGIBLE. It hes been reproduced from the best
avollable copy to permit the broadest possible avdilability. my ONLI

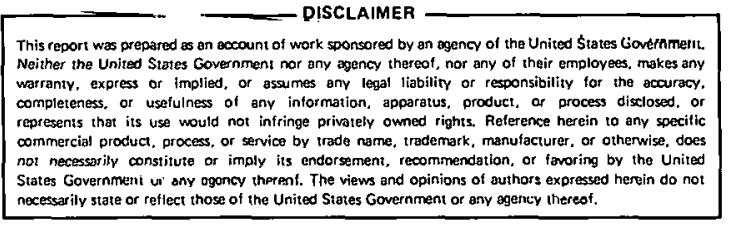


$\prod_{(A) \text { sigmal Procassing, Analysis, and Display Progman) }}$ User's Guide by

Steve Azevedo 
ANALYZE

USERS GUIDE

* Introduction ¿ History

* ANALYzE Example

* ANALYZE Structure

- ANALYZE Specifications

* Getting Started

* Options 
ANALYZE is ...

A General Program for

$\rightarrow$ Signal Processing (Filtering, Averaging.)

$\rightarrow$ Signal Analysis (Fourier, Bower spec...)

$\rightarrow$ Signal Display (port)

3 
ANALYZE

DESIGN PHILOSOPHY

(-) Plot Data on our Mini Computer

(2) Perform Simple Signal Processing

-) EASY TO USE!!

4 
HISTORY

- Nov. 1980 -- ANALYZE born plotting \& FFT

- SIPRG Members Added Features

- IEEE - DSP Package

- Some Proprietary (Releases Available)

- ANALYZE gave birth to $\rightarrow \mathbb{S}$ A0\% complete

5 


\section{EXAMPLE}





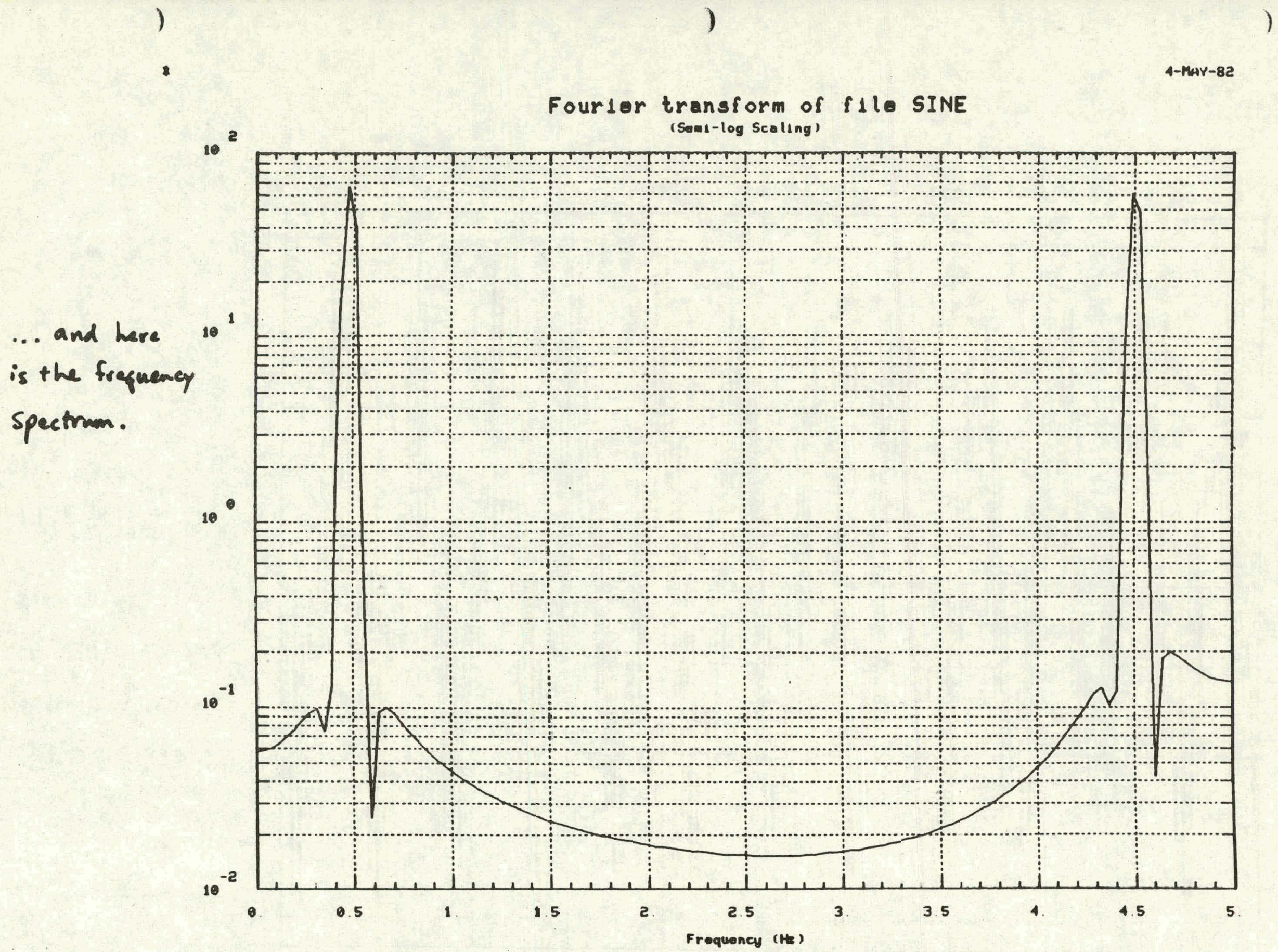


Filtered version of flle SINE

Butterworth low pass filter, Cutorf is 2000

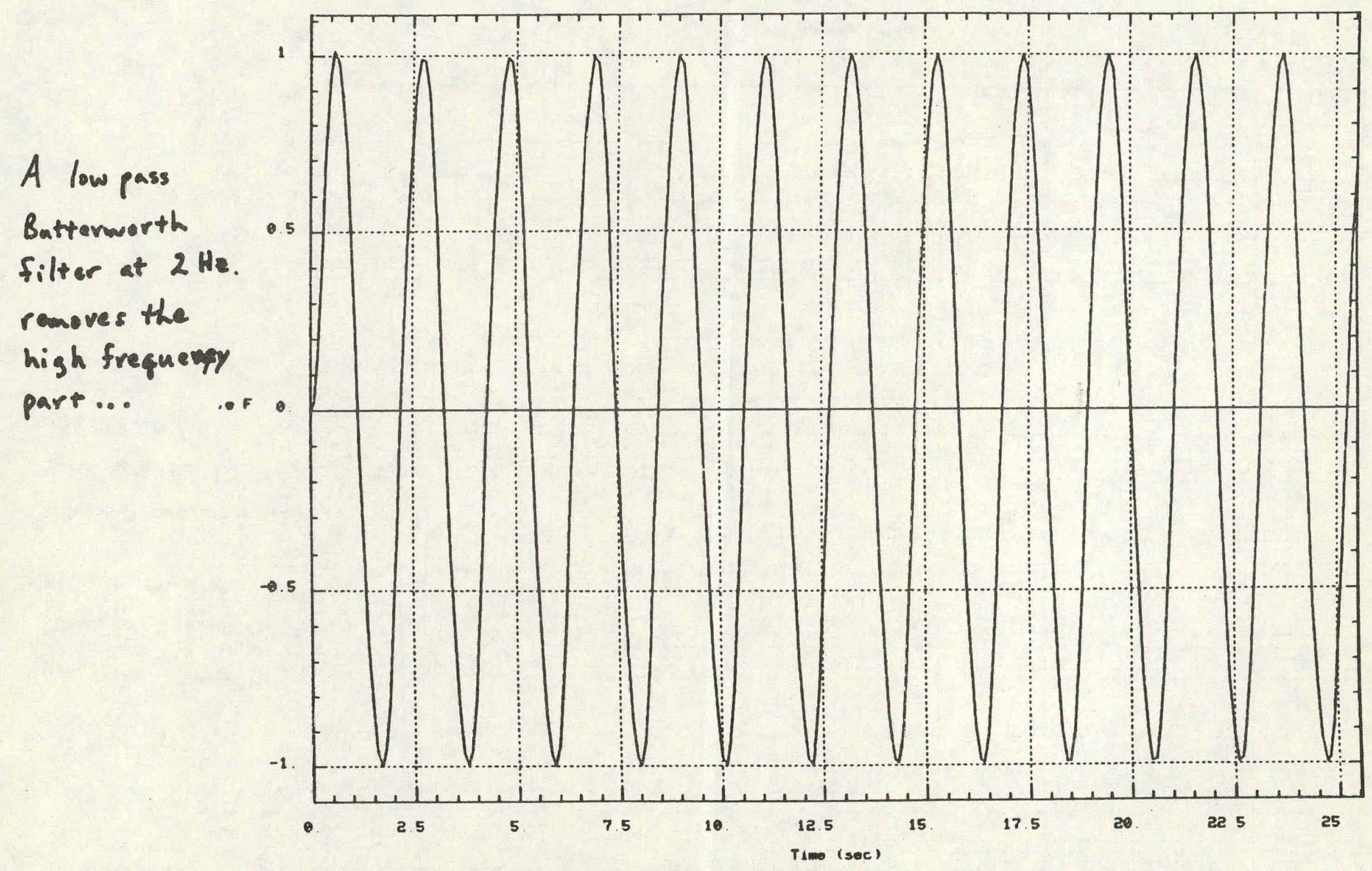




\section{Fourlor transform of 11 SINELO}

(Semi-log Scoling)

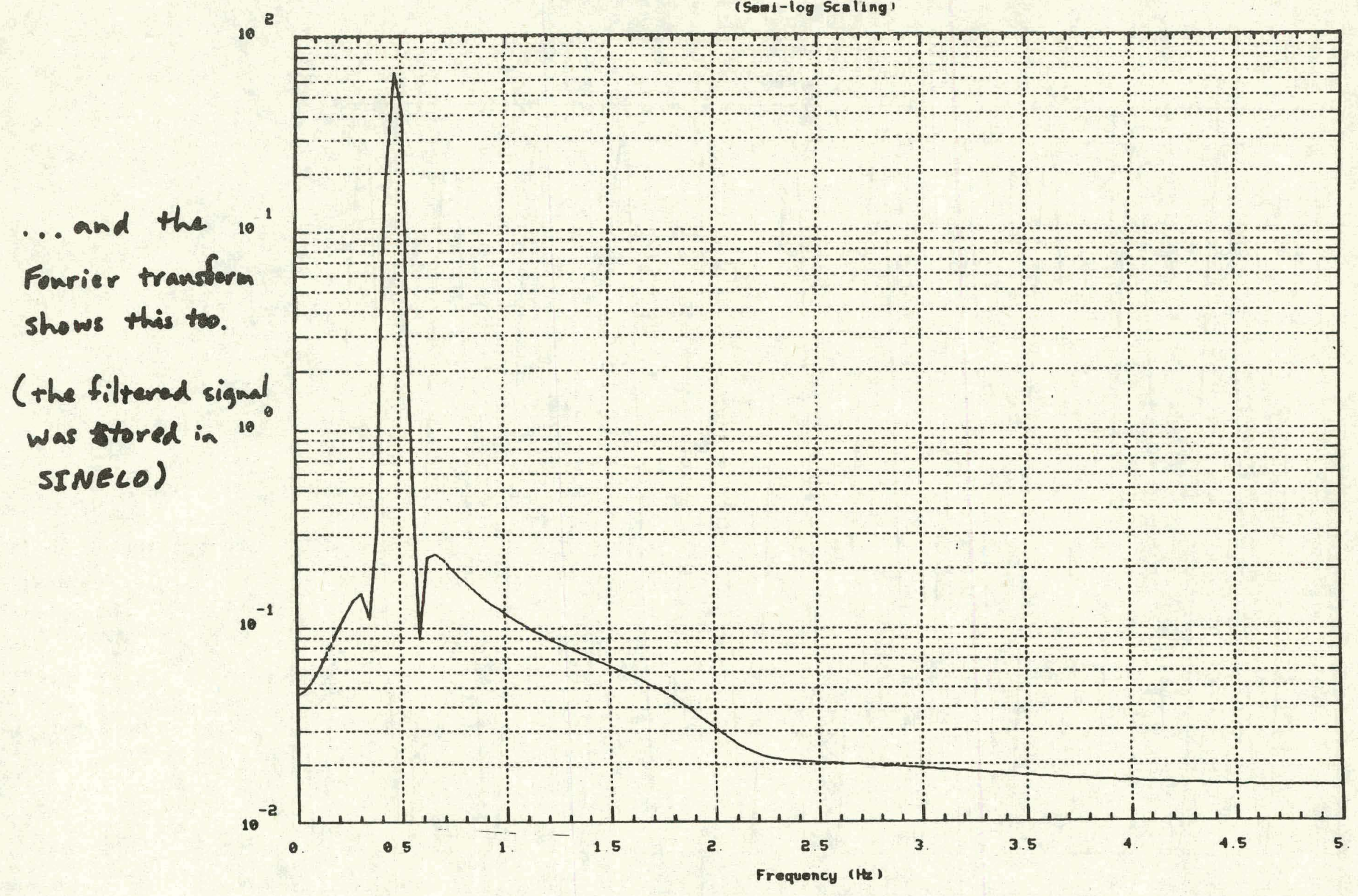




\section{ANALYZE Structure}

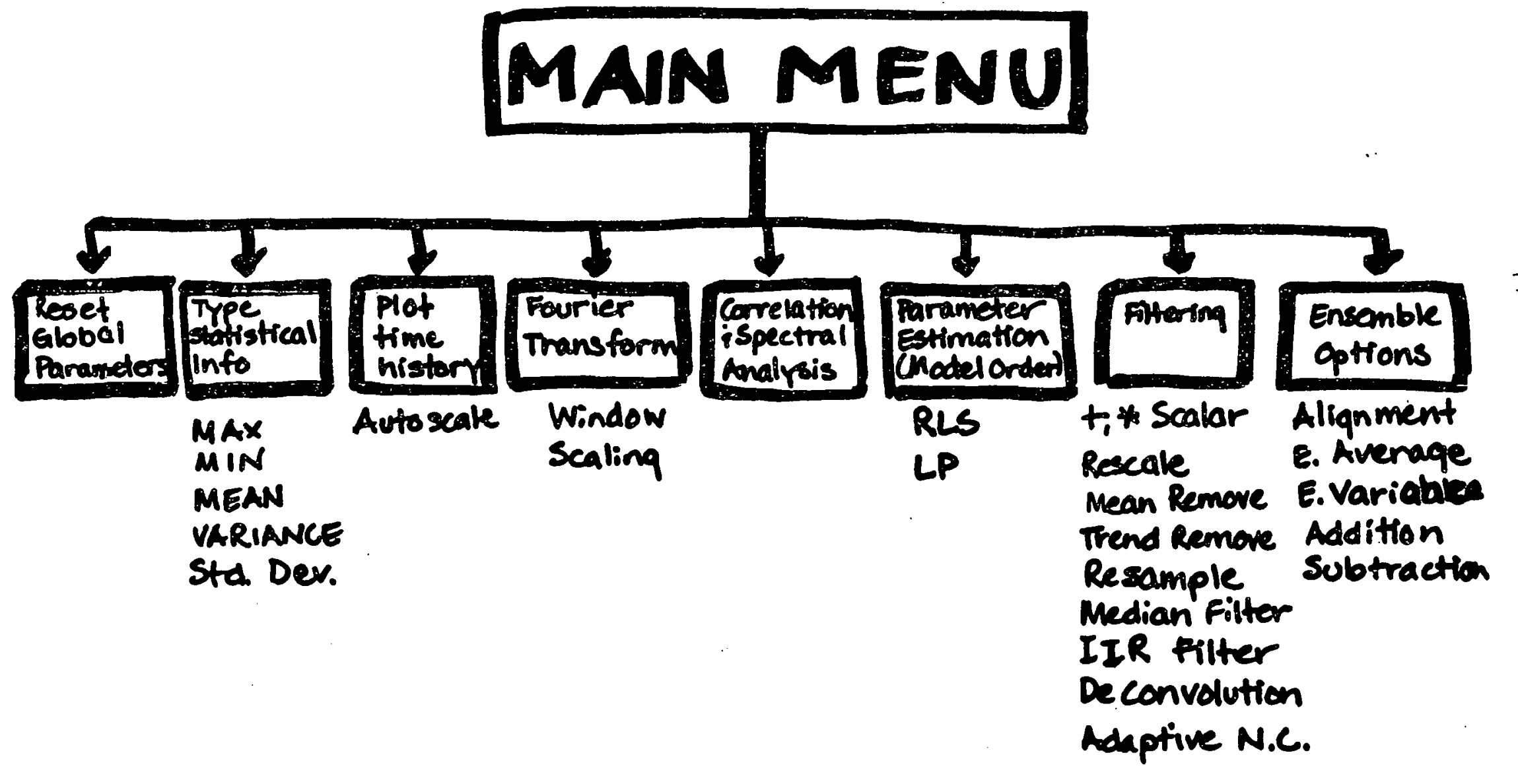


ANALYZE Specifications

FORTRAN I

DEC Machines $\left\{\begin{array}{l}\text { LI } 11 / 23 \text { using RSX - II M } \\ \text { POP } 11 / 70 \text { using IAS } \\ \text { VAX } W / 780 \text { using VMS }\end{array}\right.$

Tektronix 4014 Series Graphics (or emulator)

Uses $32 \mathrm{~K}$ Words (Ave rlard)

Menu driven (Interactive)

Simple Data Format (ASCII)

12 
Getting Started

(2) How to Invoke: $\ln$ response to system prompt, type

ANA

or to return previously stored data base ANA file hame

(2) Special characters: Rubout or Delete -- Delete previous character control $=u$-: Delete current line control = $z \quad-$ Go up one level (or exit from top)

(0) Type Ahead:

space de limited lists; If you know the questions!

13 
)

Analyze File Format

- Header (optional) -. must not have '(' in column 1 left parent

- Format specifier -. Standard FORTRAN format specifier (surrounded by parens) and followed by ...

- Data -- May be more than owe per line but must follow Format specifier.

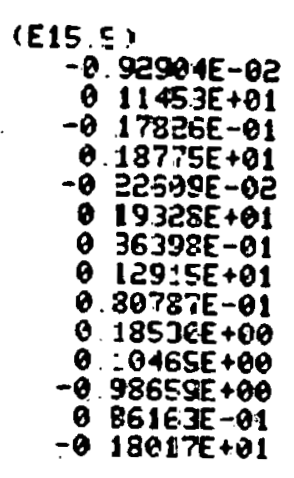

14 


\section{ANALYZE \\ Global Parameters}

$\checkmark$ File names ( $\operatorname{Max}=12)$ One signal per file

$\checkmark$ Sampling Interval

$\checkmark$ Start Sample (or time)

$\checkmark$ Number of Samples

(final time) $(\operatorname{Max}=1024$ ) 
OPTIONS 
Signal Analysis Program

Type the number of the option requested

4-MaY-82

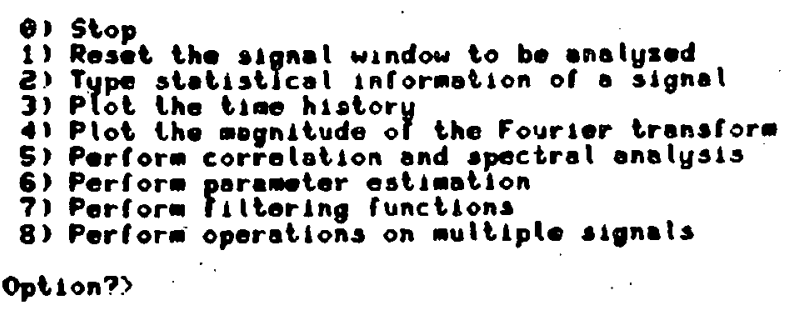

Option??

This is the main menu displayed when you type ANA

Typing ' $\varnothing$ ' in response to 'Option? $>$ ' will exit the program.

17 


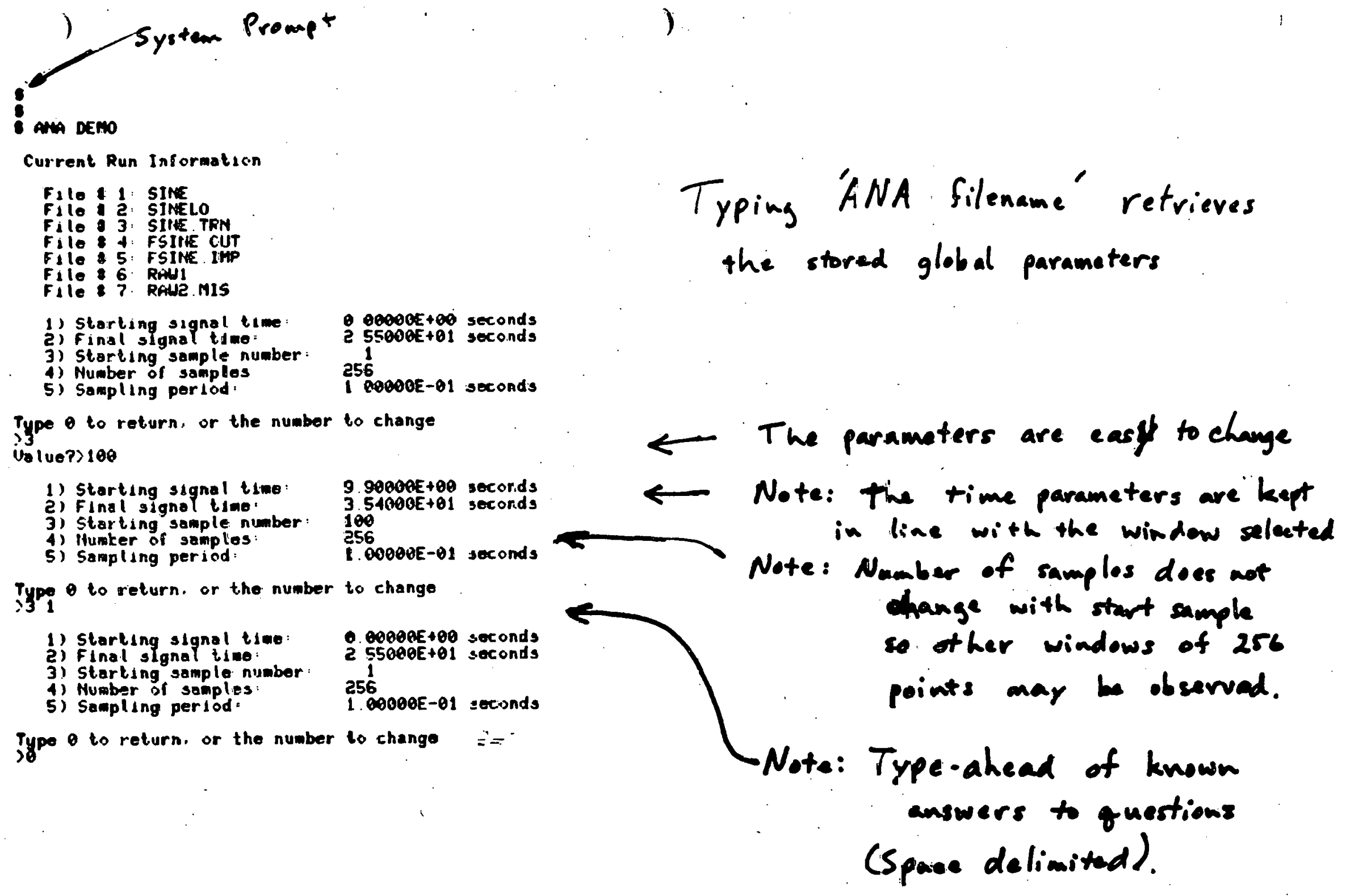




\section{Signal Analysts Program}

Type the aurber of the option requested

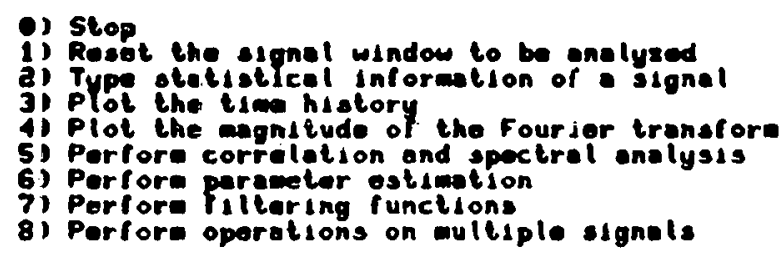

File 4. Fsine our

Filo 5. Fsithe In

File 6 : RANI

1) Starting slgnal tico. $0.00000+00$ seconds

a) Finel slgnal tine: $2.55000 \mathrm{E}+01$ seconds

3) Starting sanple numbar

5) Sampling portod.

256

1 coever-ot seconds

Type to relurn. or the number to change

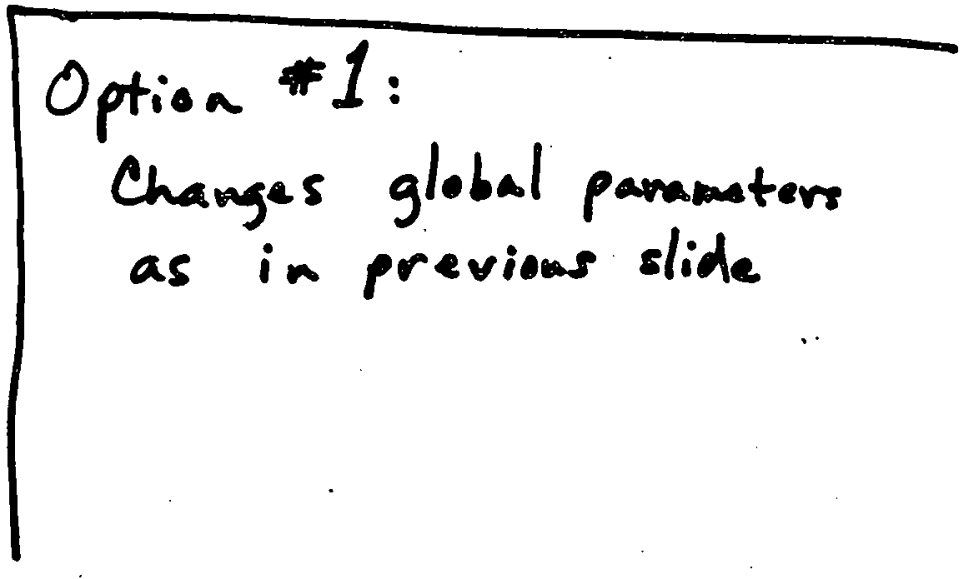




\section{Signal Analys1.s Program}

Type the number of the eption requested

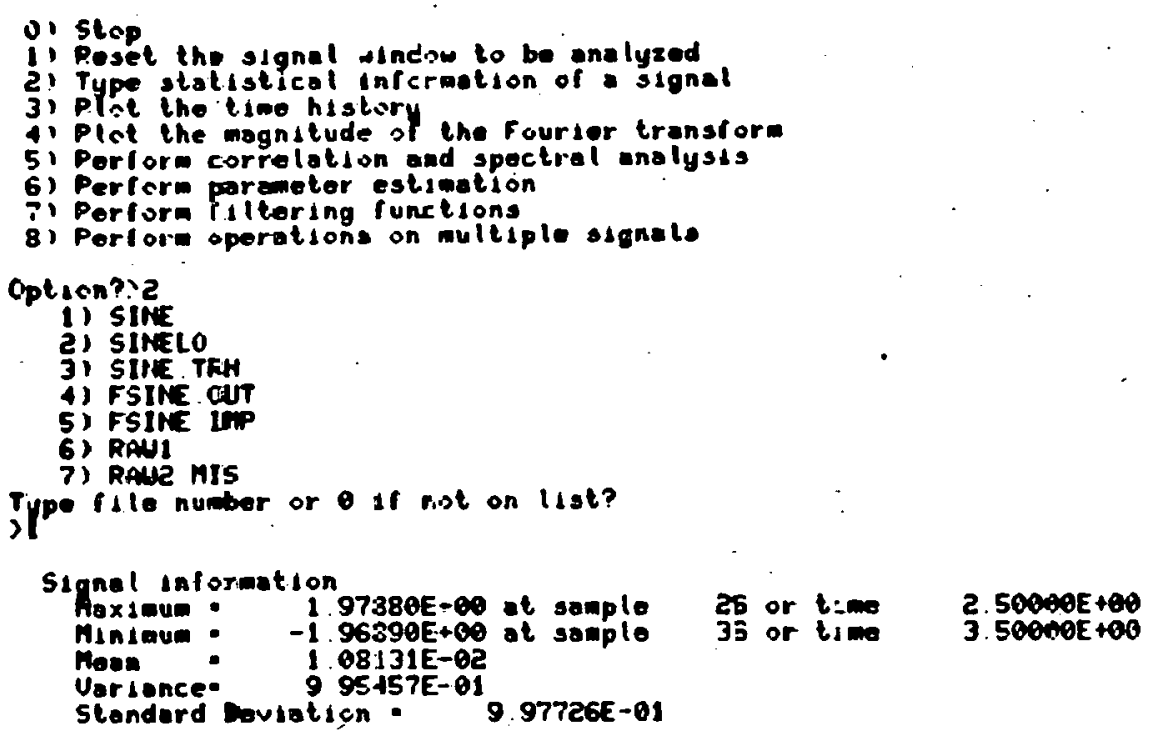

Oplion?s
Option \#2:

Displays statistieal information 
Signal Analysis Program

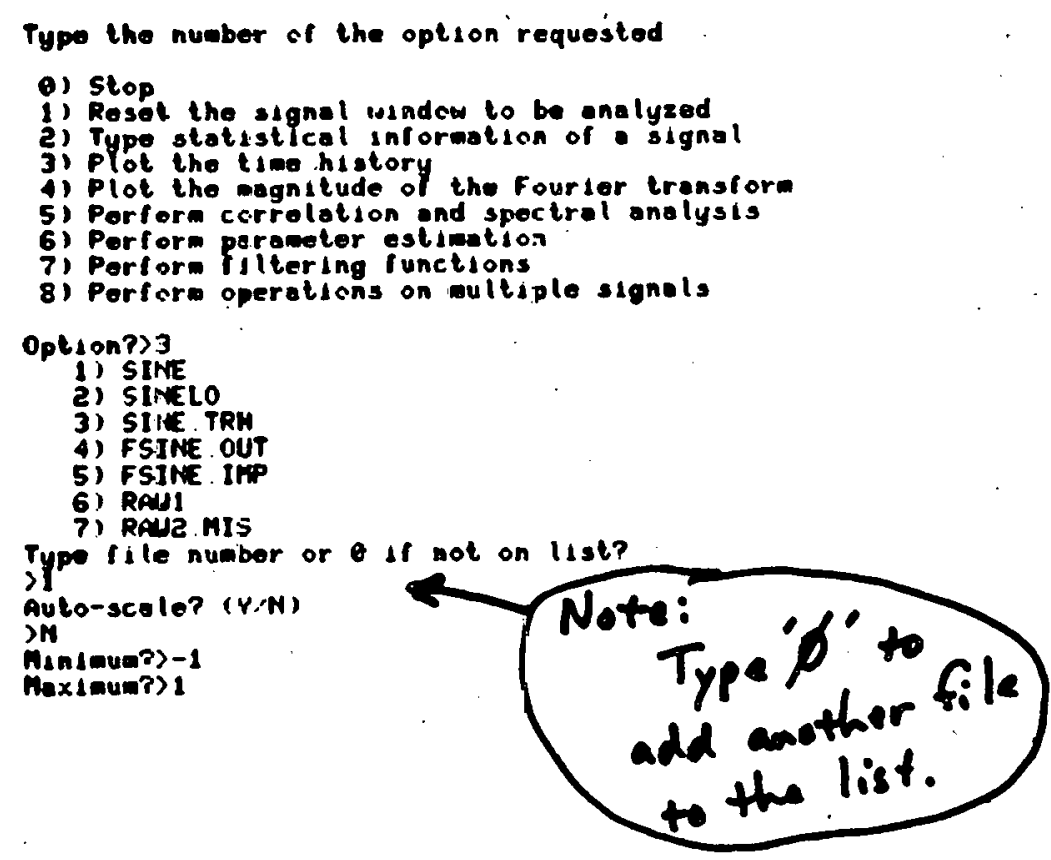

Option \#3:

Time History plot.

May provide your own vertical scaling.

21 


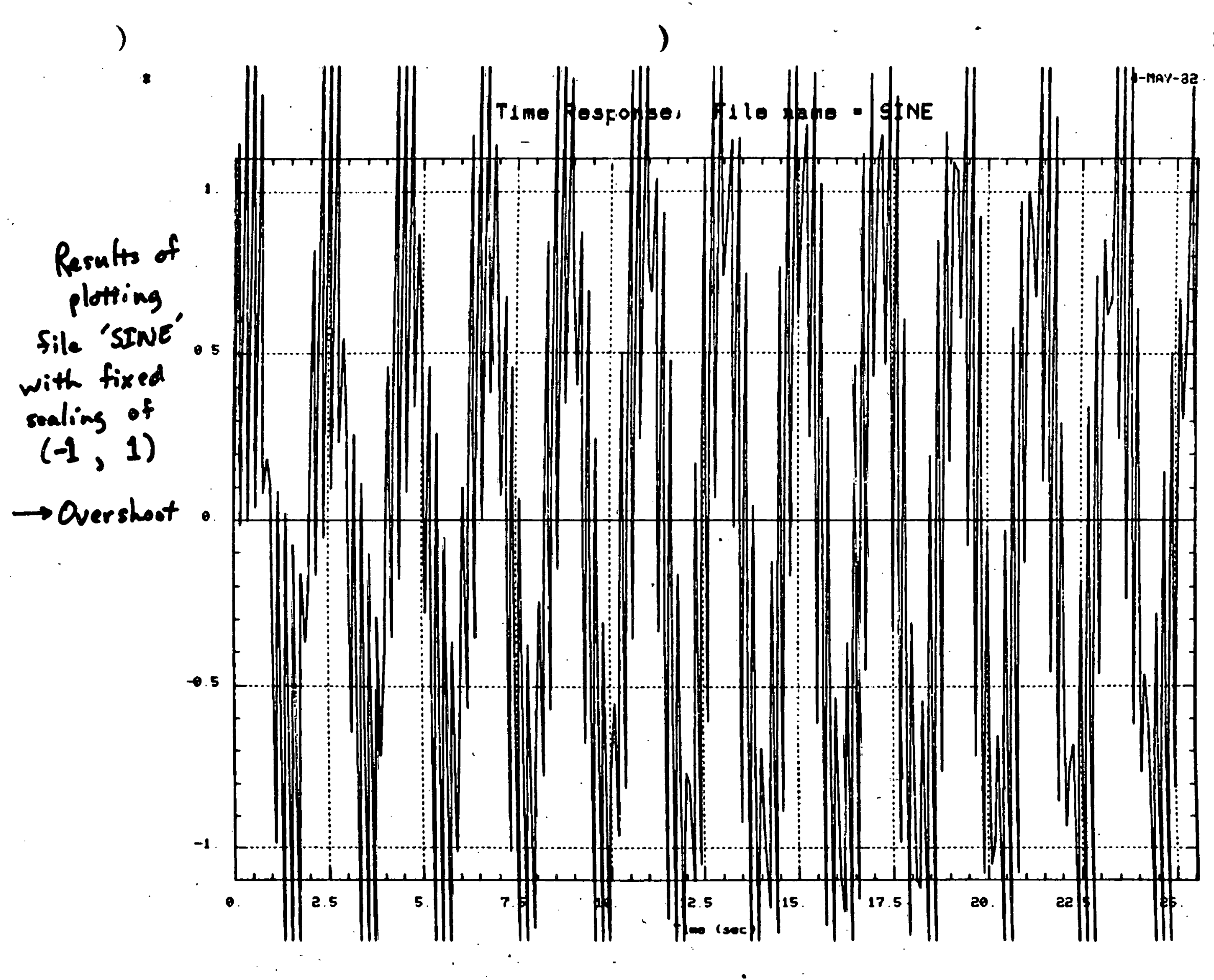


Signal Analysis Program

Typo the nuaber of the optson requested

0) slop.

1) Reset the signel window to be enolyzed

2) Type stetistical information of signal

3) Plot the tim history

4) Plot the magnitude of the Fourjer transform

$5)$ Perform corralation and apectral analysis

$6)$ Perior paramoter ostiantion

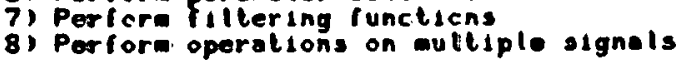

Option?: 4

1) SIME

3) SIMEL The

4) FSINE. OU

5) FSINE ITP

6) RANI HIS

Type ille nuaber or 0 if not on list?

FFT size. 256

Uindow typo (O-Rect. I-Hanm. .z-Hann.)

$>0$

SCaling? (1=LIN. 2-XLIN-YLOG, 3-XLOG-YLIN, 4-LOG-LOG, O-EXIt)

se

to. of Irequency posints. Ha29, How many to plot?

stert rroq. point and no. points? (az to exit)

11

Theber of points?

$\therefore-$
Option \#4:

EFT Plot " FFT

$\rightarrow 3$ types of windows

Rectangalar

Hamening

Hanning

$\rightarrow 4$ types of axis sealing

$\rightarrow$ May view parts of 


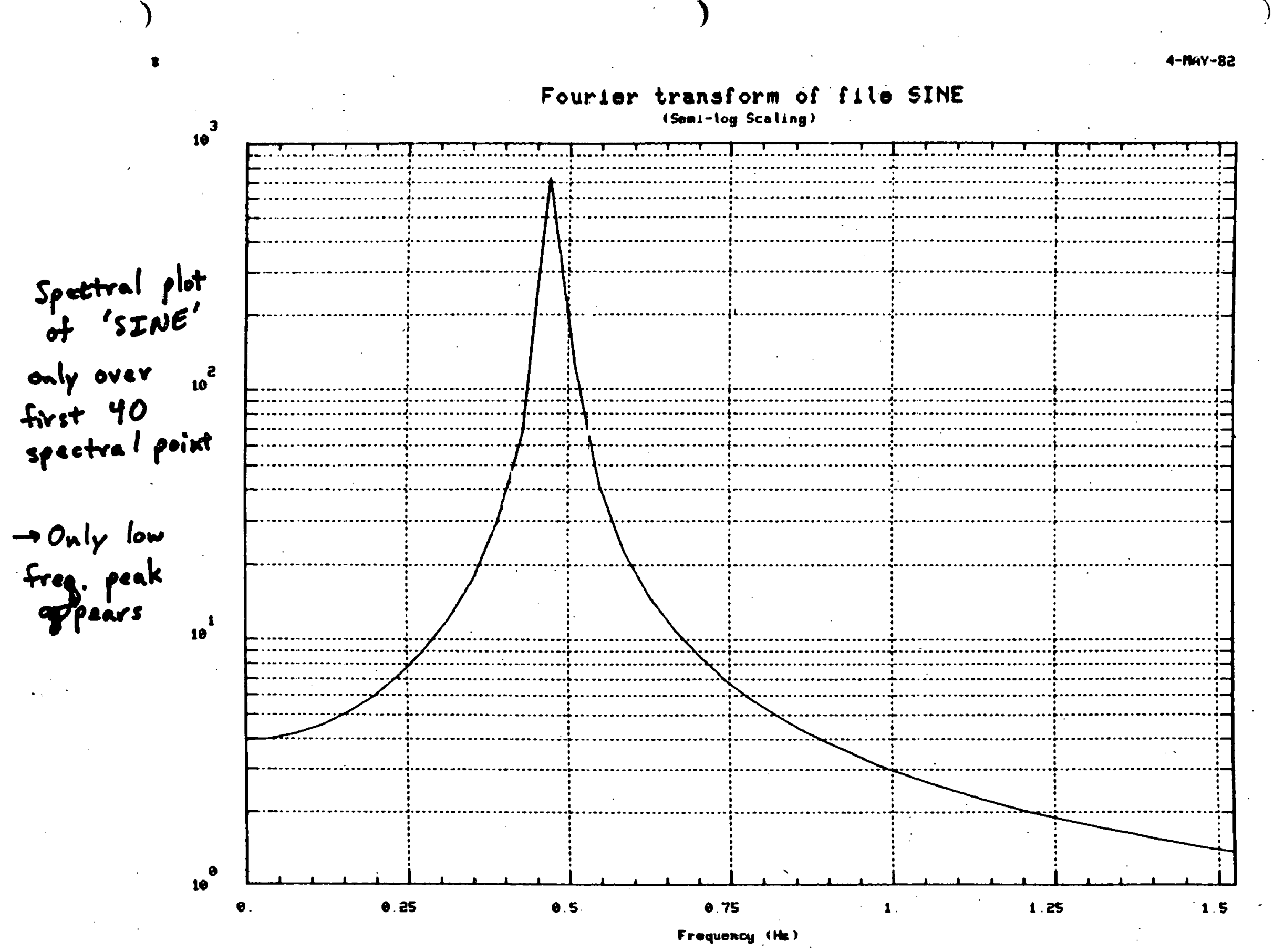


Correlation and Spectral Analysis

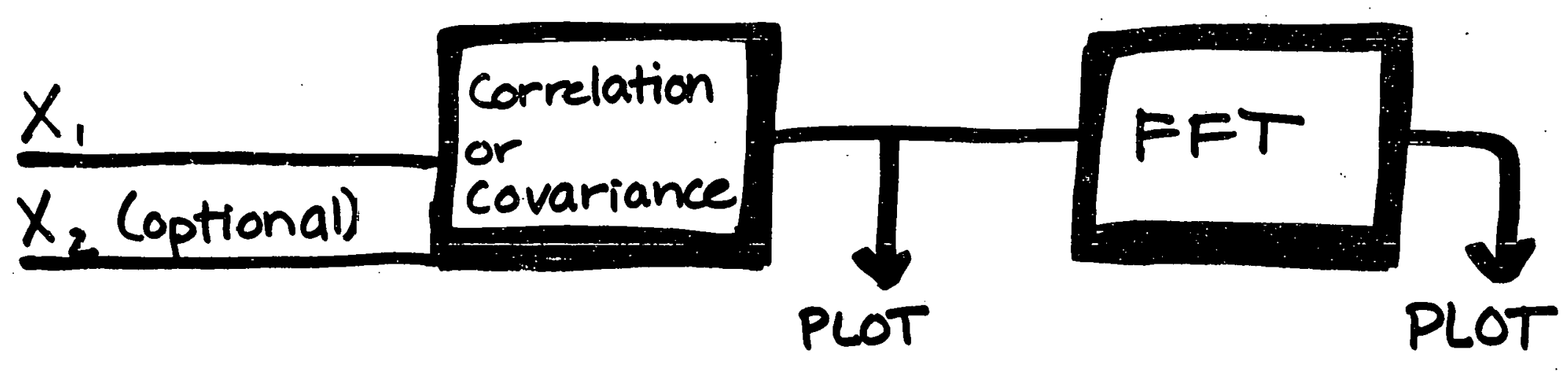

Operates on 1024 sample sections of input

25 


\section{Power Spectral Estimation}

This acgeonl uses the corrolalion mothod tyr powar spoctral estimetion described in chaptor 2.2 of eprograes for oigilat sigral Procossing", odited by tho DSP Comaitteo of the IEEE-ASSP Sociely. IEEE Pross. 1979.

First. 2ho algarithm computes tho auto- (or cross-) corrolelion (or covarlance) function and plats il

Men. this corrolation iunction is windowed (Reclengular, Heaing. or Hanning) to a (1xed lengh. L. and Feurlercansformed to eblain the power spectrel estimate

a large $i$ guves a narrow spectrum with oreator detall.

That tupe of correlation?

a) Rolurn

I Autocorralation

C) Cross-corretation

3) Aulocoveriance

Mumber? 3

1) SINE

3) SIIFE. TRoA

4) FSIIE ONT

5) FSINE ItP

6) RAN1

Type itlo number or 0 il not on 11st?

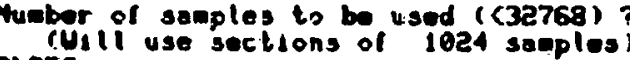

cut il use sections of 1024 samples)

\section{7)ES6}

Munber

of correletion valuos usod (L)?

Uindor

Sealing $(0-11$ noer. $1-d B)$ ?

Optien \#S: Power Spectral Estimation

Note: May use up to $32 \mathrm{~K}$ samples.

Does not use "Namber of samples" global pareanotior 


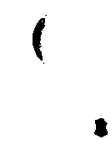

4-Mwr-82

Autocovarlance Function Filo : SINE

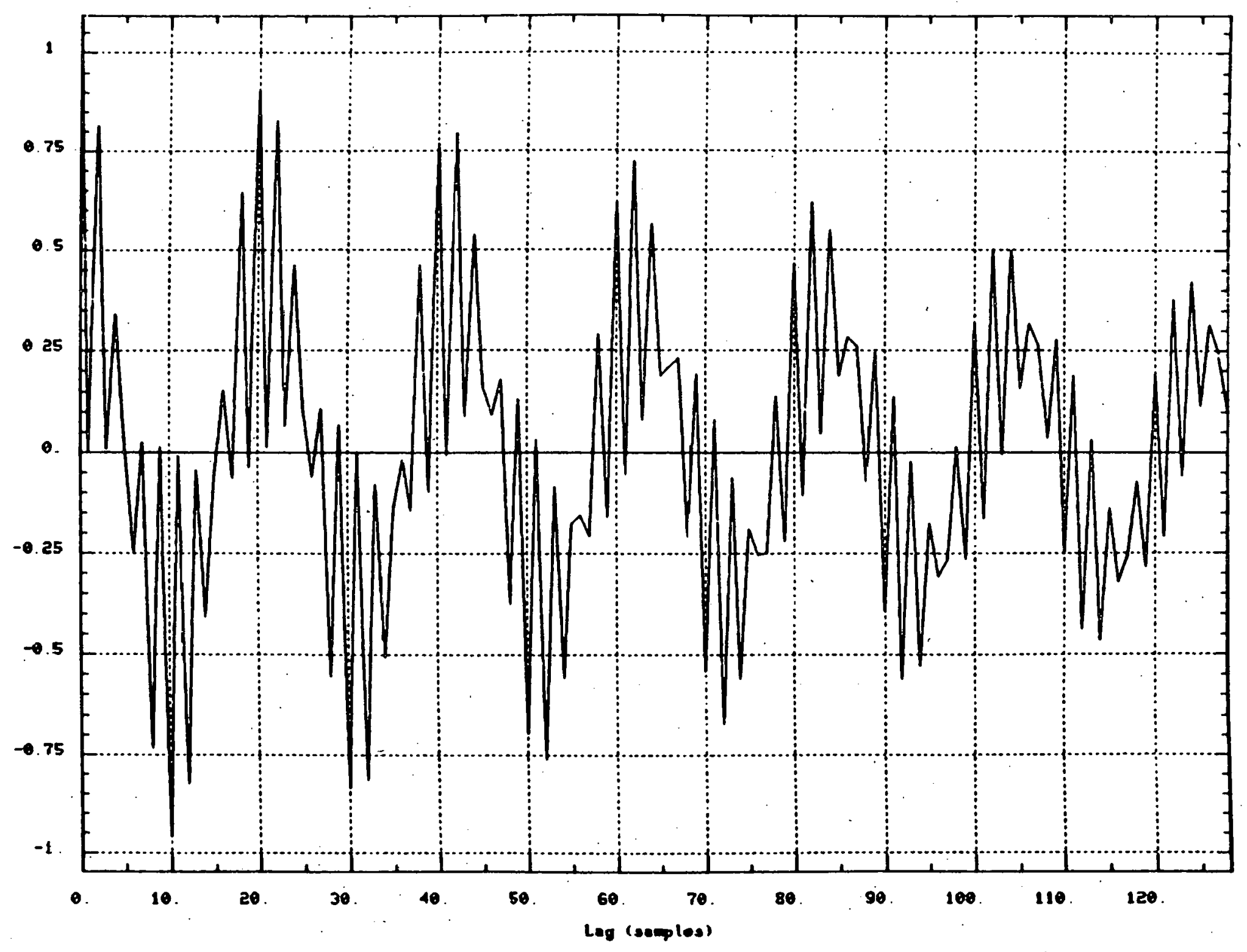


$\bullet$

Powe: Spectral Estimate (dB)

file. SiNe

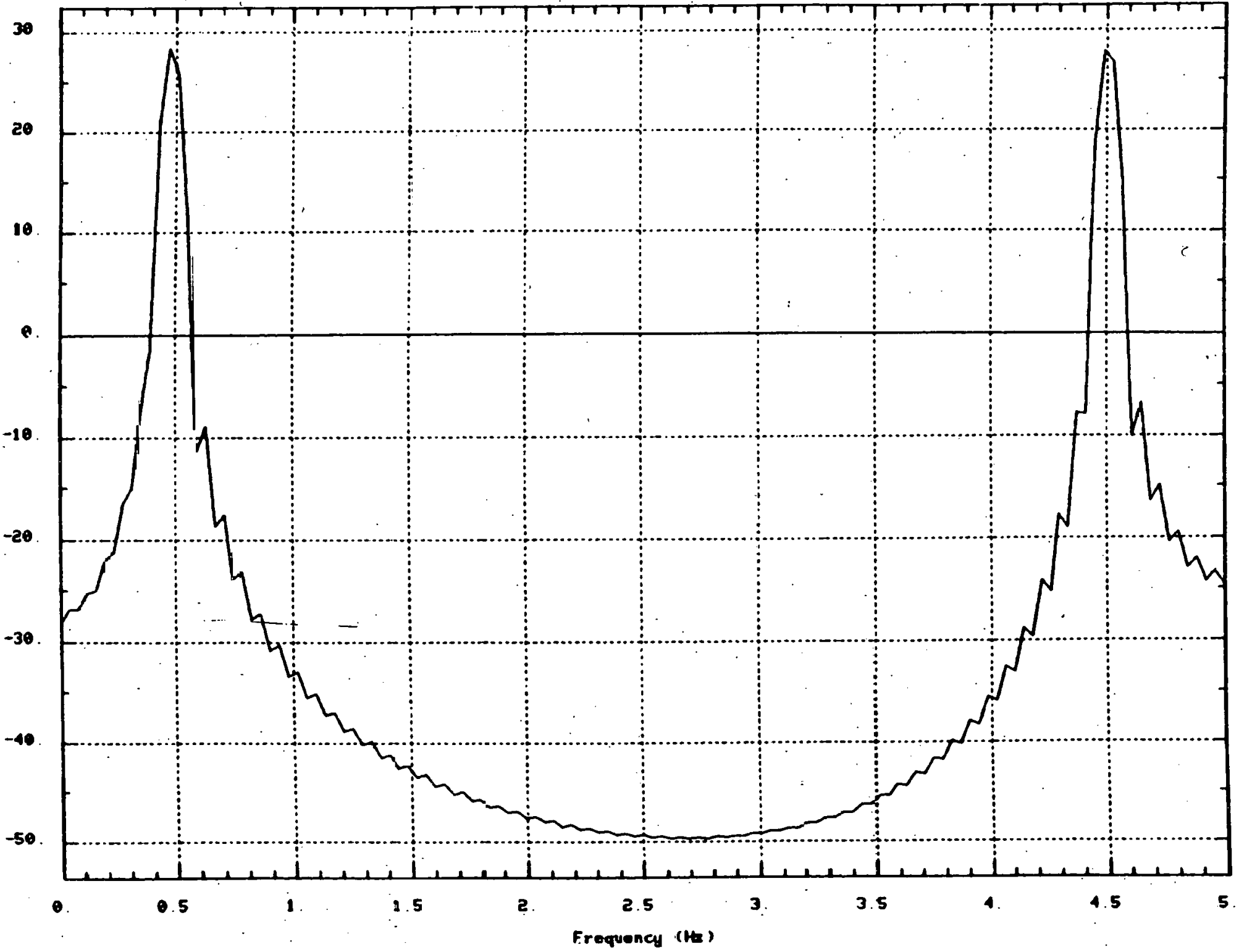


Model Order Estimation

* Problem : Determine the order of a model describing a signal

* Solution : (1) Fit several order models

(2) Determine sum of squared errors

(3) Plot Error vs. Order

29 
4-nkir-32

Paramotor Est1mation

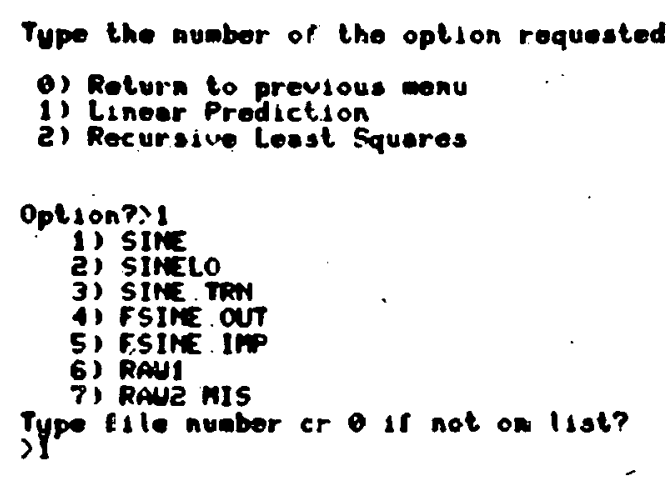

An order test is porformed on the signel, and
plocted then you ney request to oxantine the coefficients.

Option \#6:

heximu ordor for arror plot?

Parameter Estimation

$\rightarrow$ Lineor Prediction

$\rightarrow$ RLS

30 
?

4-MAY-92

Linear Prediction Error Plots

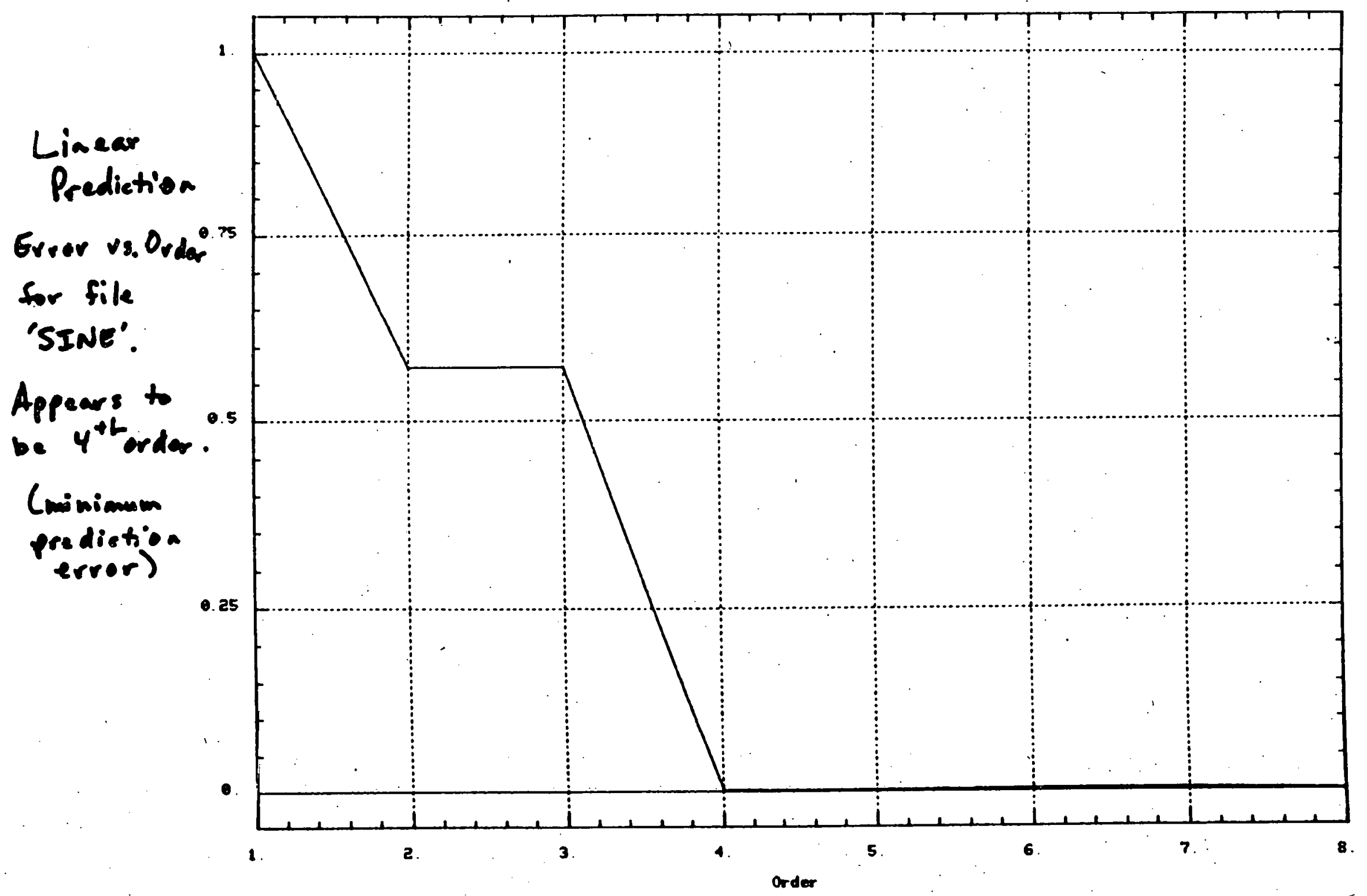

$\therefore--$

31 


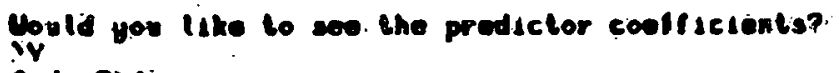

Orders 4

Predictor Coefficients

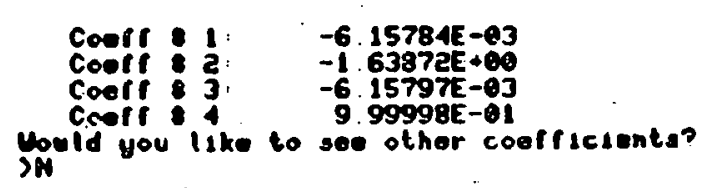

Also may get a list of coefficients for a particular order

32 
Filtering Functions

(Option 7 in main menu)

Functions

1) Subtract scalar

2) Multiply scalar

3) Rescale (desired min max)

4) Mean removal

are not covered but are simple (Try them!)

33 
Friremars Function \#5.

Trend Removal

* Problem: Remove a "trend" in the data of order $N$.

* Solution: (1) Fit the data with $\begin{aligned} & N^{\text {th }} \text { order polynomial } \\ & \hat{y}(t)=\hat{a}_{0}+\hat{a}_{1} t+\hat{a}_{2} t^{2}+\ldots \hat{a}_{N} t^{t}\end{aligned}$

(2) Subtract from data $z(t)=y(t)-\hat{y}(t)$

34 
Filtering Functions

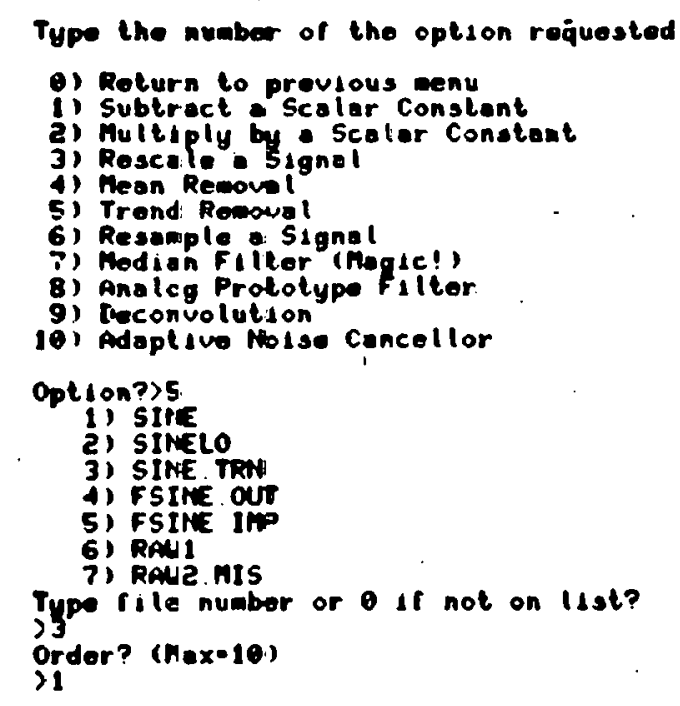

Funetrow +5

Trend Removal

35 
Trend of flle SINE.TRN

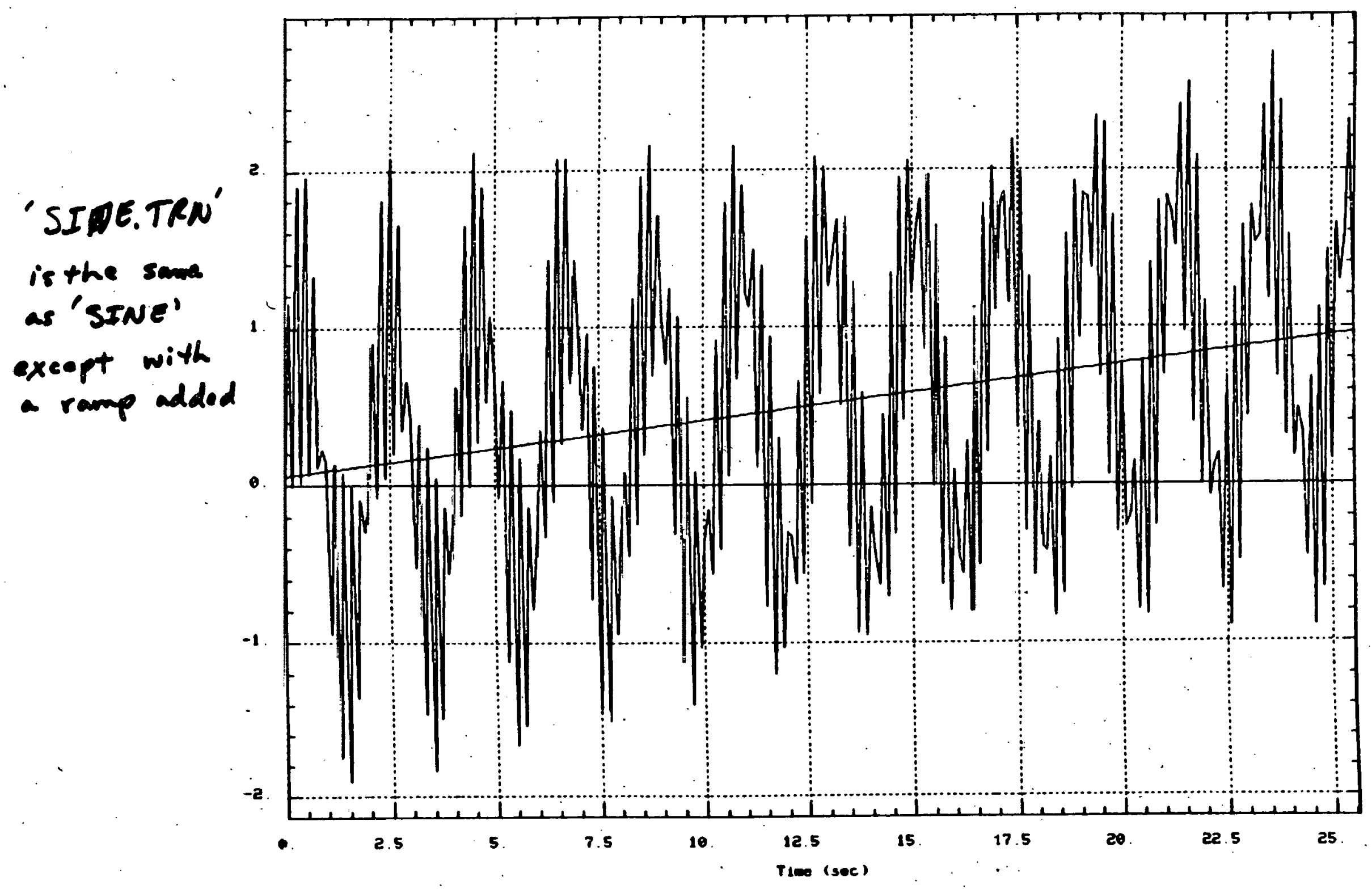




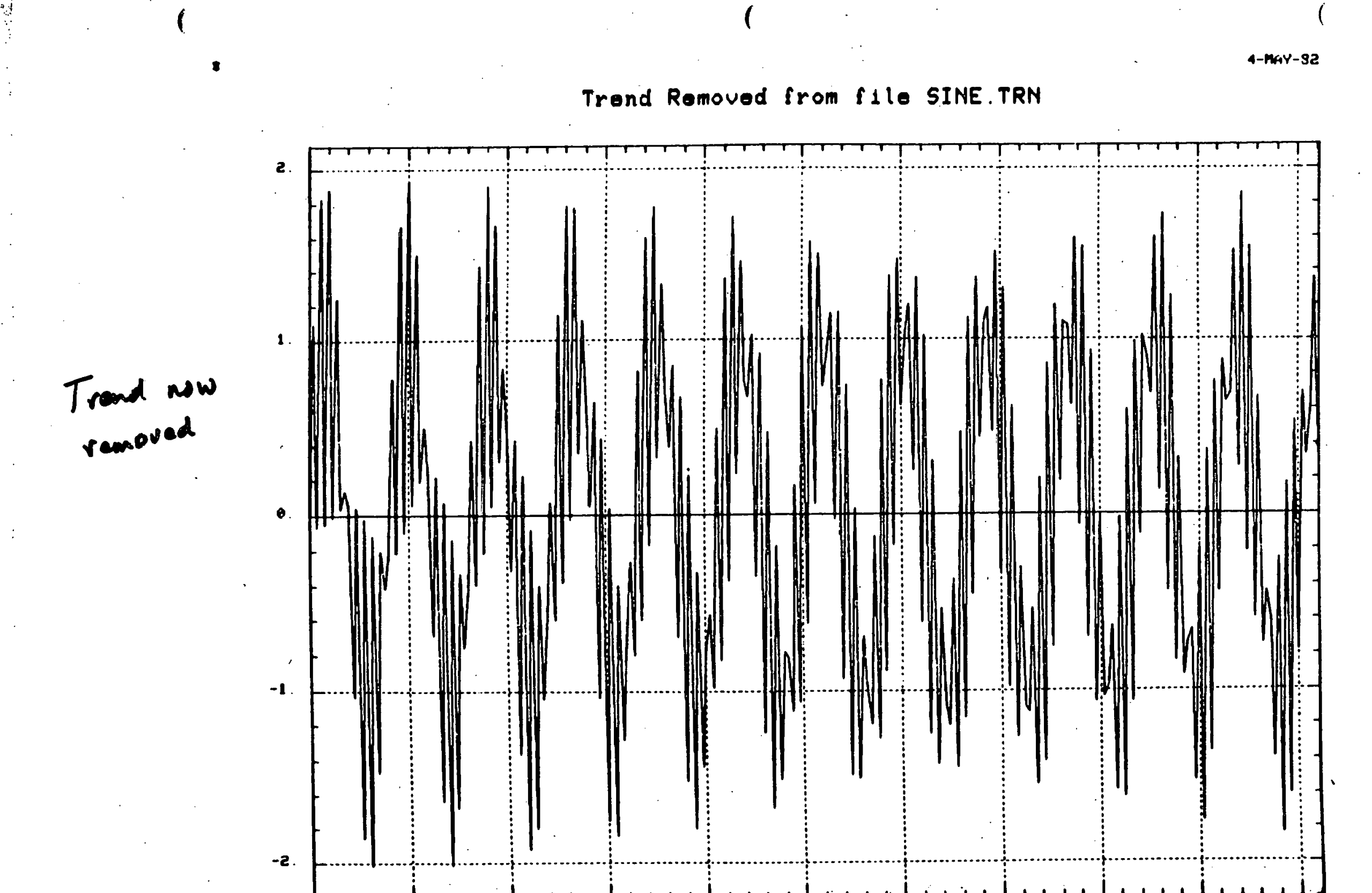


Filtering Function \#6

Resample

- Interpolate or Decimate

(1) MUST Filter Before Decimating

(-) Must Filter after interpolating because zeroes added between points

Only by integer amounts

38 
Filtoring Functions

4-mar-82

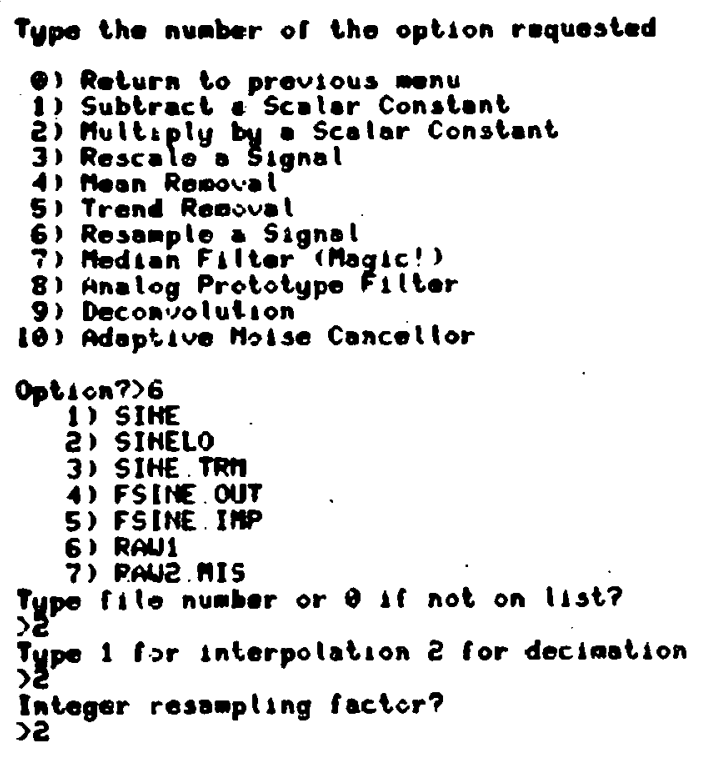

$\frac{\text { Funstion \#6: }}{\text { Resample }}$ Interpolate or decimate

39 


\section{Resampled vorsion of file SINELO \\ sompling interval - 2 coece-01}

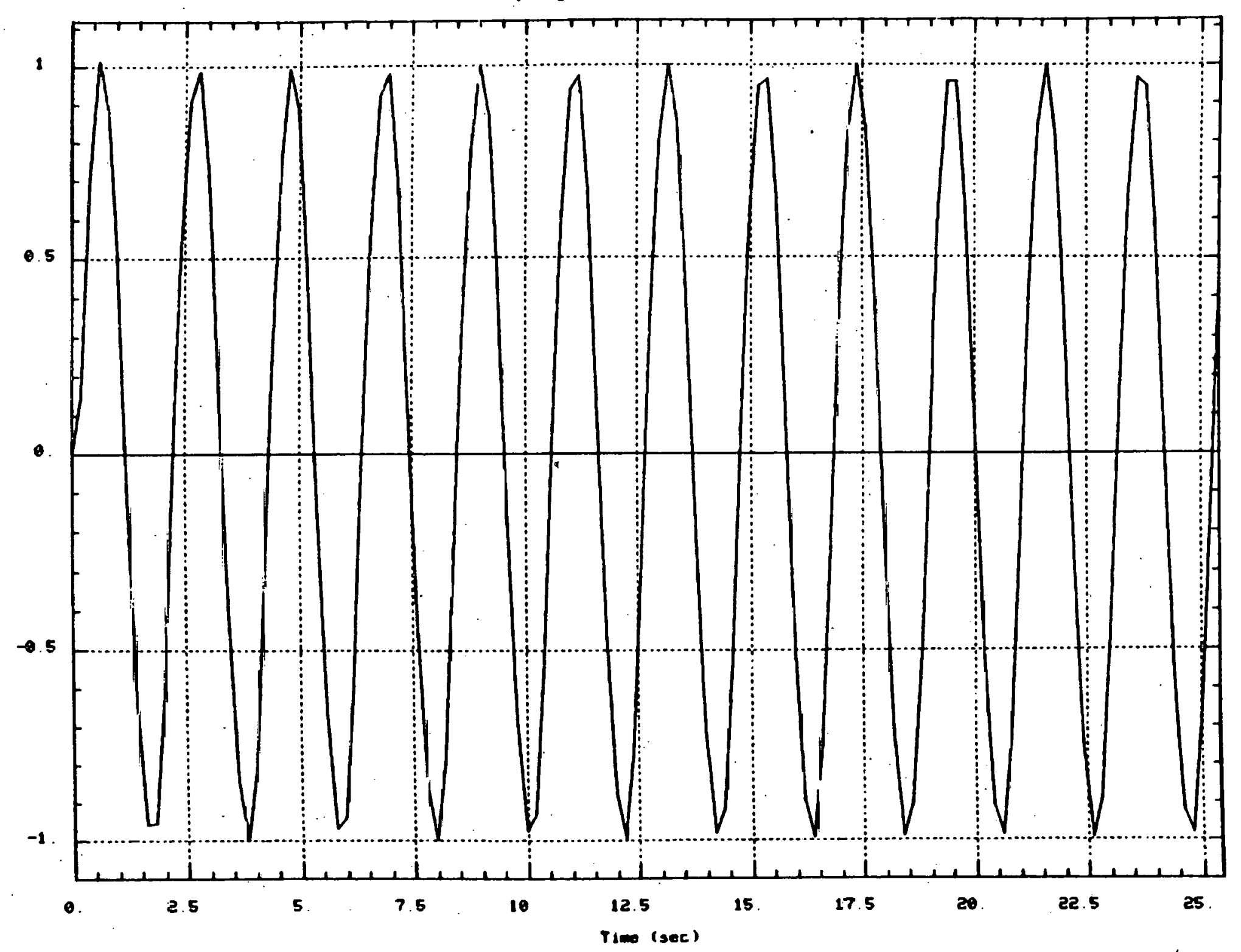


Filtering Function \#2.

Median Filter

$\checkmark$ Median Value in a window

$\checkmark$ Removes spurious spikes

$\checkmark 3,5$, and $7^{\text {th }}$ order

Example:

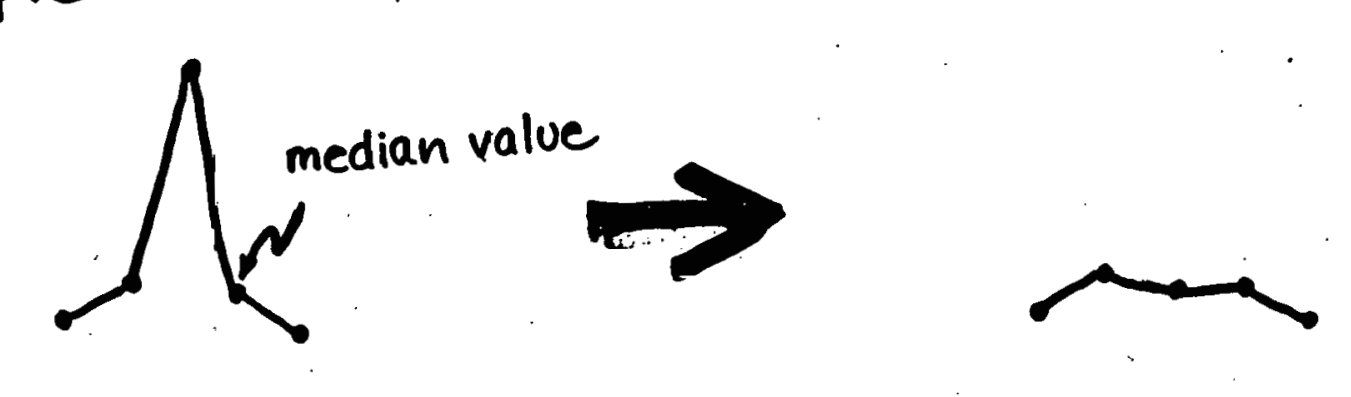

41 
Filtoring Functions

Typo the number of the option requested

i) Roturn to proulous anu

1) Subtract scalar Constane

2) Nulleply by - Scalar Constent

3) Roscale signal

5.) Trend Romoval

5.) Trend Romoval.

7) Median Fillor (Magle!)

8 Anelog Prolotypo fllter

101 Adaptise Melso Cancellor

option?]?

1) sing

3) sine. Ten

4) FSINE OUT

5) FSINE IMP

6) RAUI MIS

Type rile number or 0 if not on list?

Filier order (3.5.er 7)?

Function \#?:

Median Filter 
(

(

$4-n+i-82$ Filterod vorsion of file SINE
nodien illtored order.

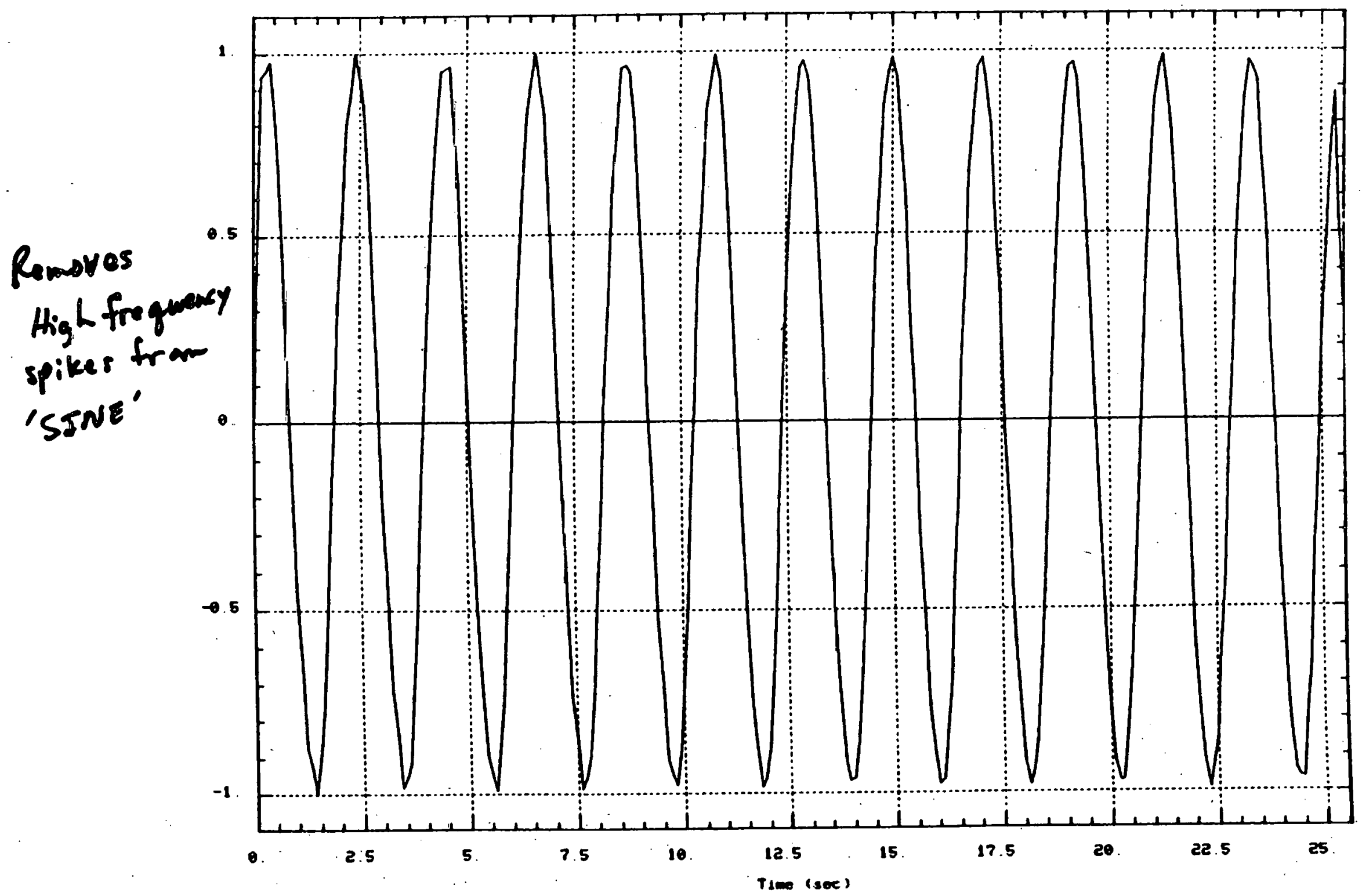

43 
)

Filtering Function \#8

ANALOG PROTOTYPE (IER) FILTERS

Choice of:

: Butter worth Low Pass

Bessel Band Pass

: Chebysher I High Pass

Chebyshev II Band Reject
Oforward : Backward

o Several Orders

44 
Filtering Functions

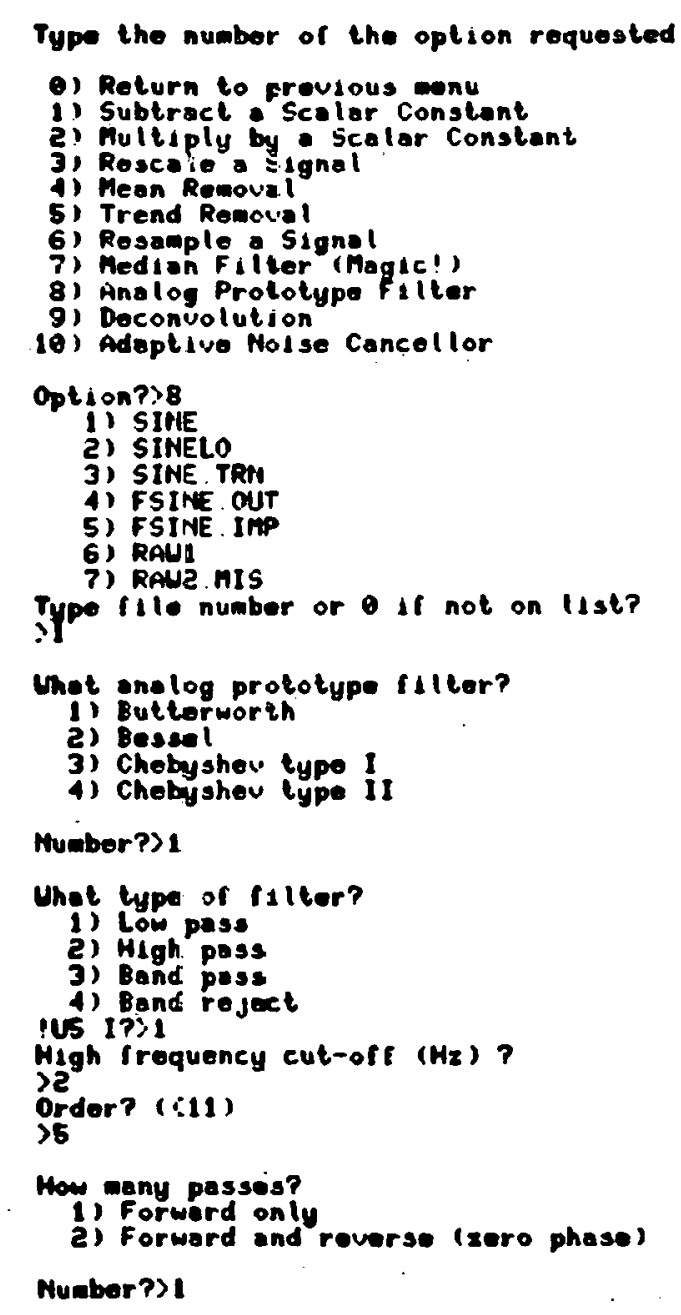

Function \#8:

Analog Prototype (IIR) Filters

45 


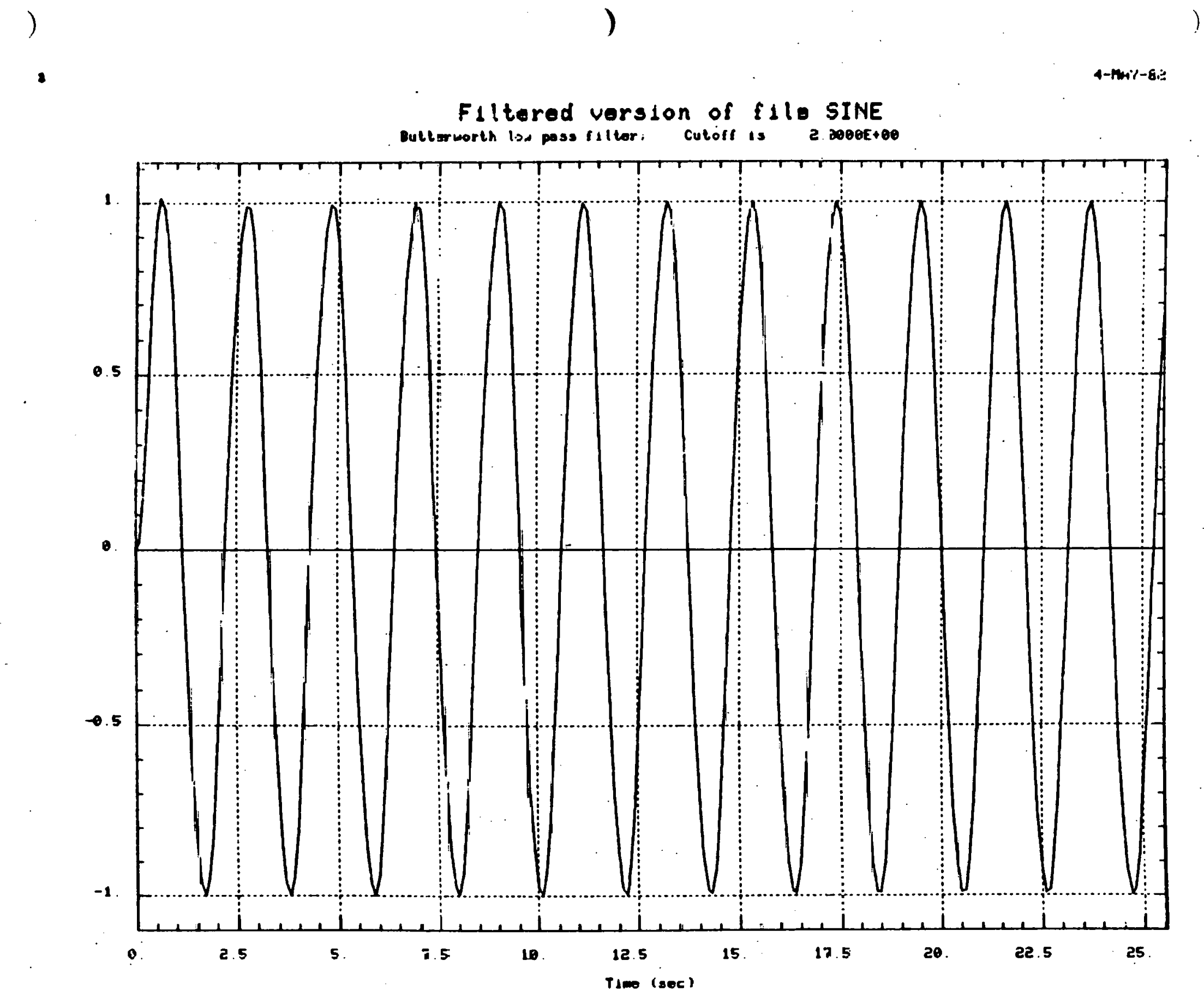


Filtering Function \#9

Deconvolution

* Problem: Deconvolve the input, $u$, given out put, $y$,
and impulse response, $h$. $\stackrel{u_{k}}{\longrightarrow} h_{k} \stackrel{y_{k}}{\longrightarrow}$

T Solution: (1) Find inverse filter $h^{-1}$

(2) convolve $y$

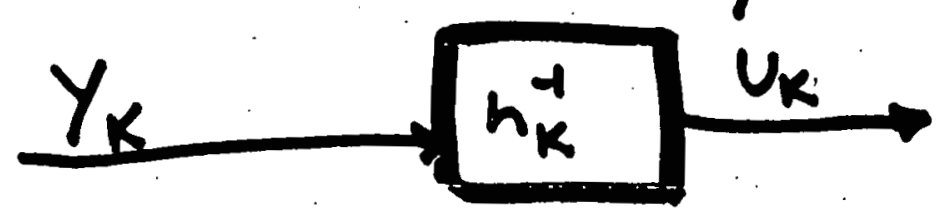

47 


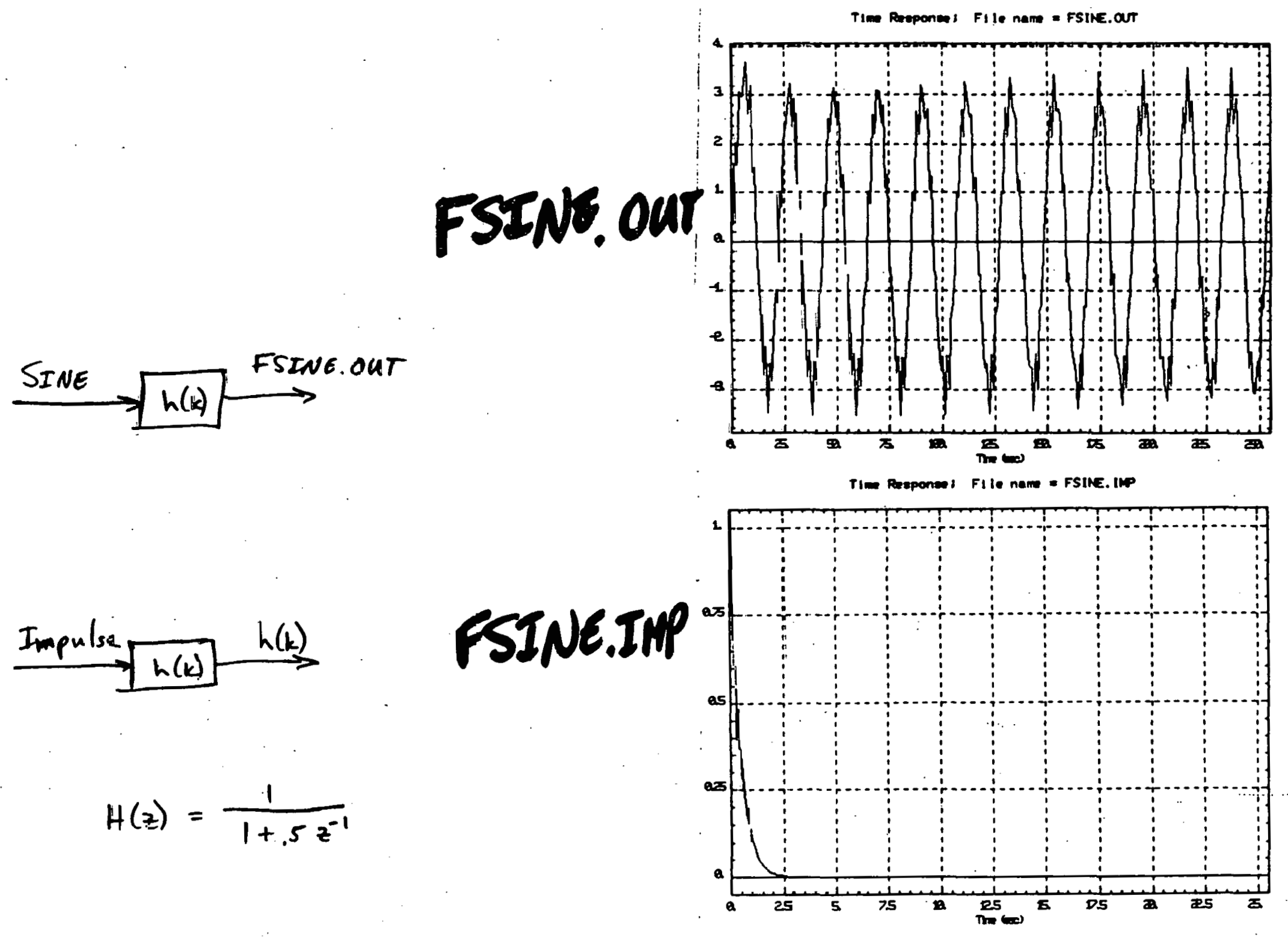

48 
Flltering Functions

Type the number of the option requested

A) Roturn to provious oonu

2) Multipl a Scalar Constant

3) Rescalo by a Seal

1) Moan Reacusiol

6) Trend Rewnew

6) Resample Eignol

7) Modion Filtor (Hogle!)

B) Analog Prototype Filier

9) Doconvelution

Option?s9

This rouline deconvolves the frequency response of

one dola-get from ancther. This is done by designing o prediclion arrur filter on the first signal ( $h)$ and applying it to the socend, $a$. glven the following diograp

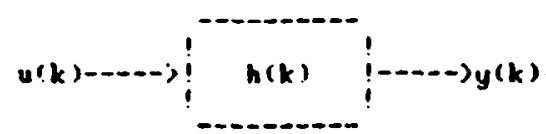

The usar onters h and $y$, and the algorithm compules $u$.

at first onter the sawe data-set) $h(k)$ kt

i) SIME

2) SINE

3) SINE TRN

1) FSINE Out

5) FSINE InP

6) RANi

RAUE MIS

Type lilo number or if nol on list?

it second onter the 11 lo containing $y(k)$ it

i) SINE

2) SINELO

3) SINE. TRM

5) Fsine. Our

6) RAWl

Type rile number or -11 not on list?

slart sample for modeling window?

$i_{1}$

Modeling window lenglh?

$>50$

Mumber of illter coofificients
Function \#9

\section{Deconvolution}


Deconvolution of FSINE. OUT

From llle FsINE. InP

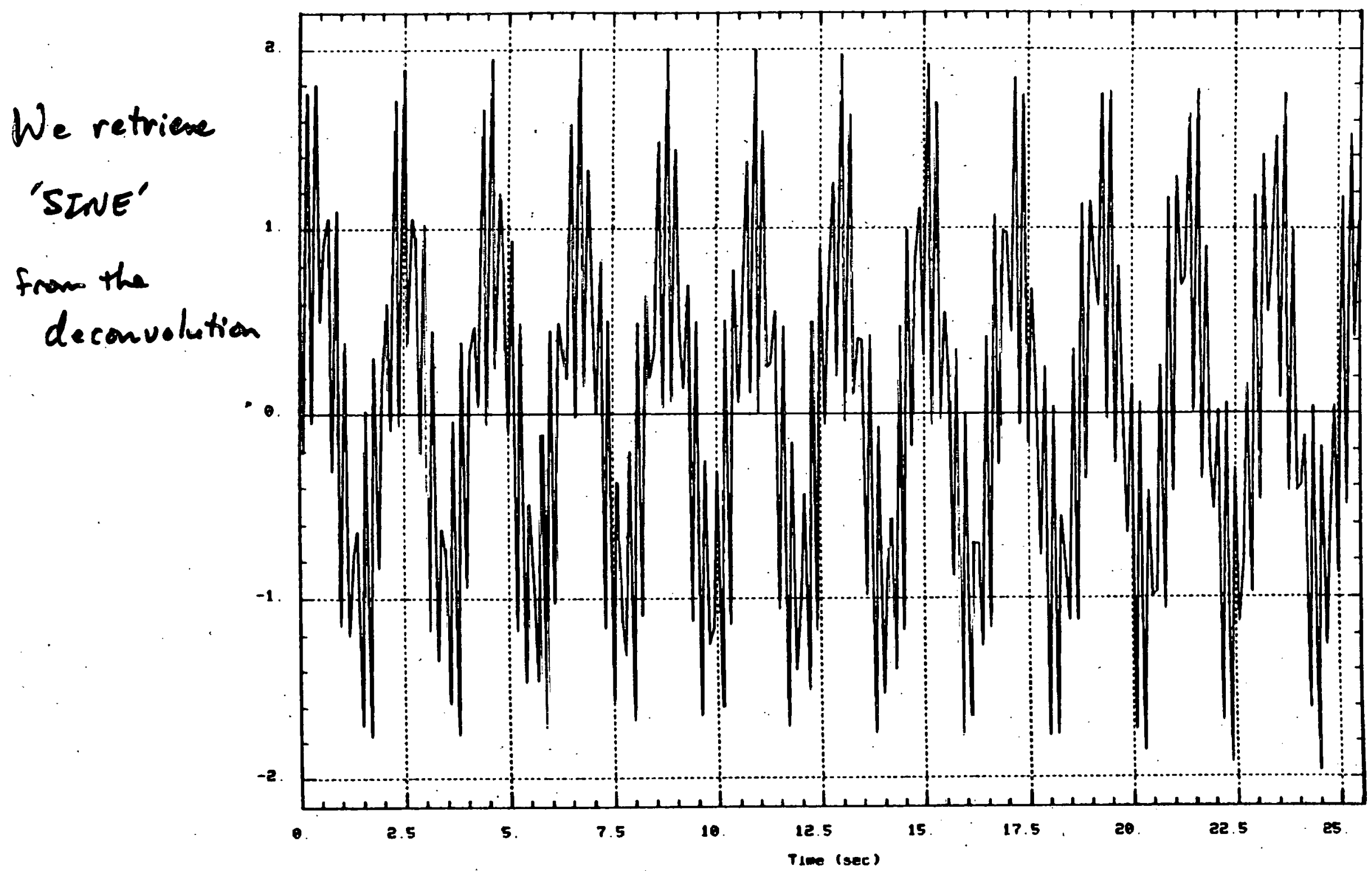


Filtering Function * 10

ADAPTIVE NOISE CANCELLER

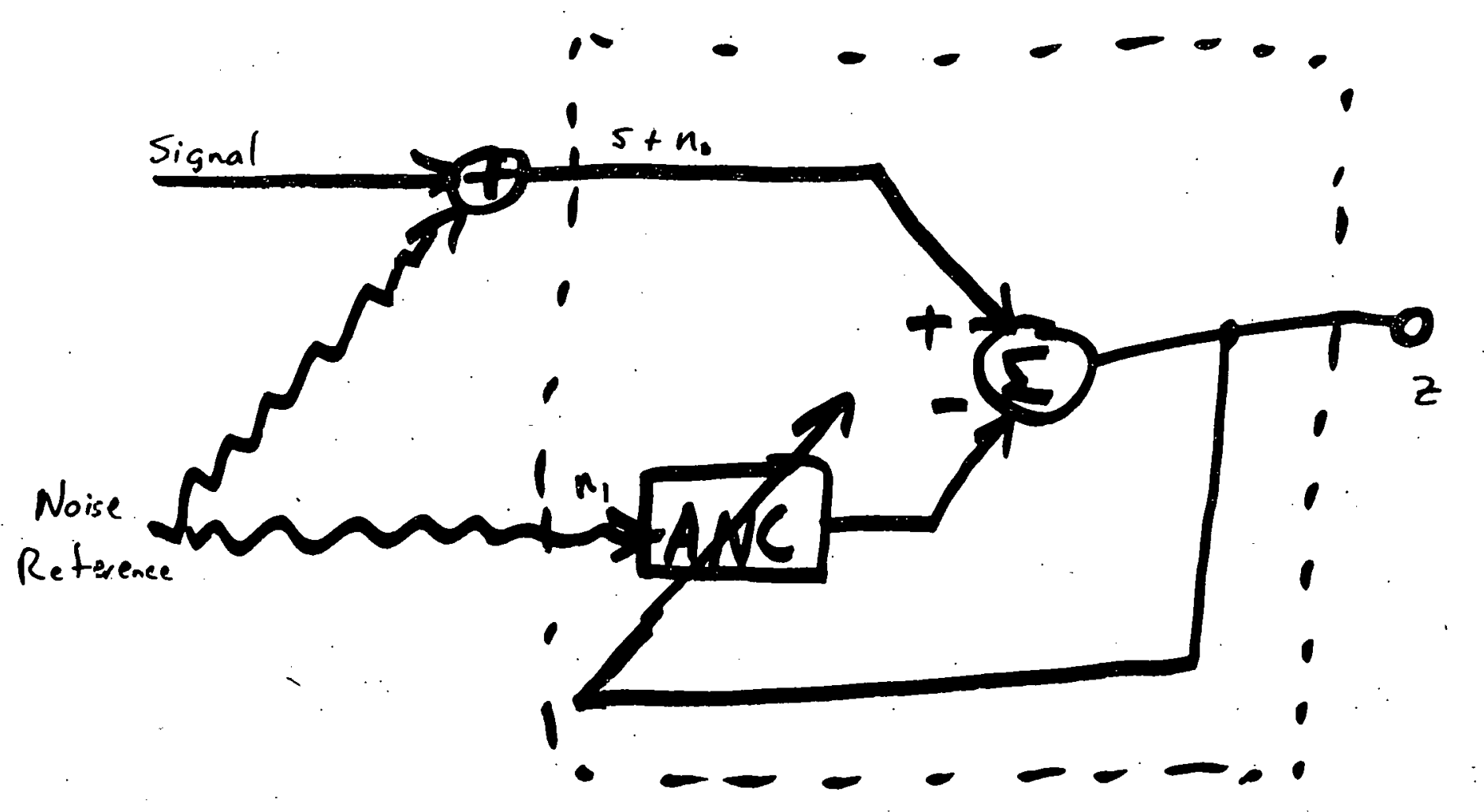

5) 
4-mai-82

Filtering Functions

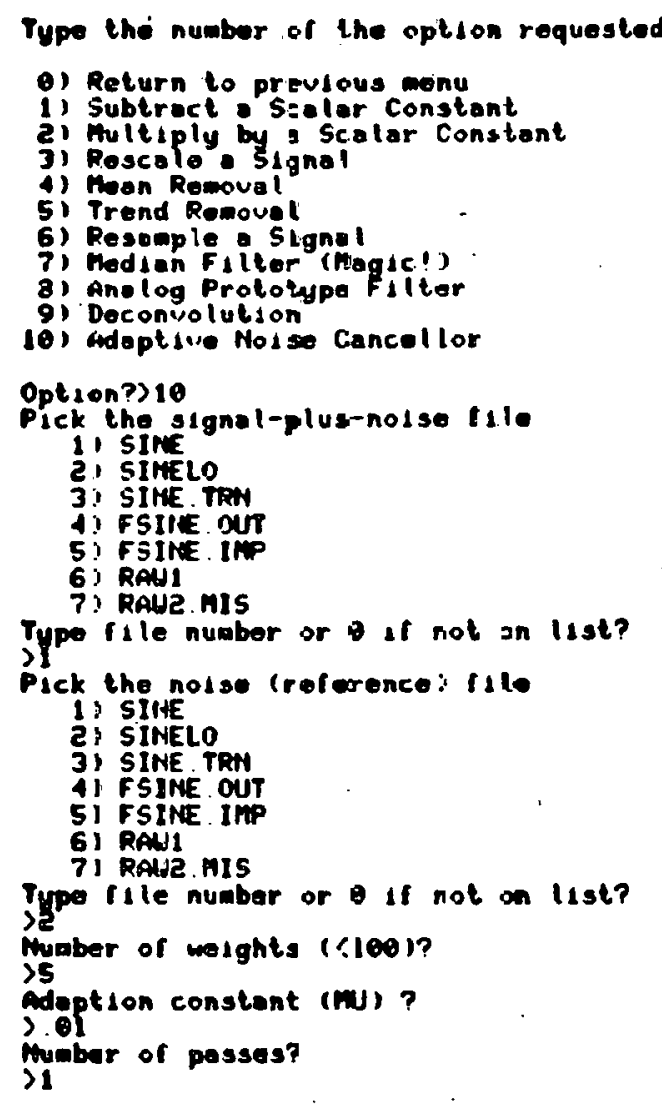

Function * 10

Adaptive Noise Canceller

52 


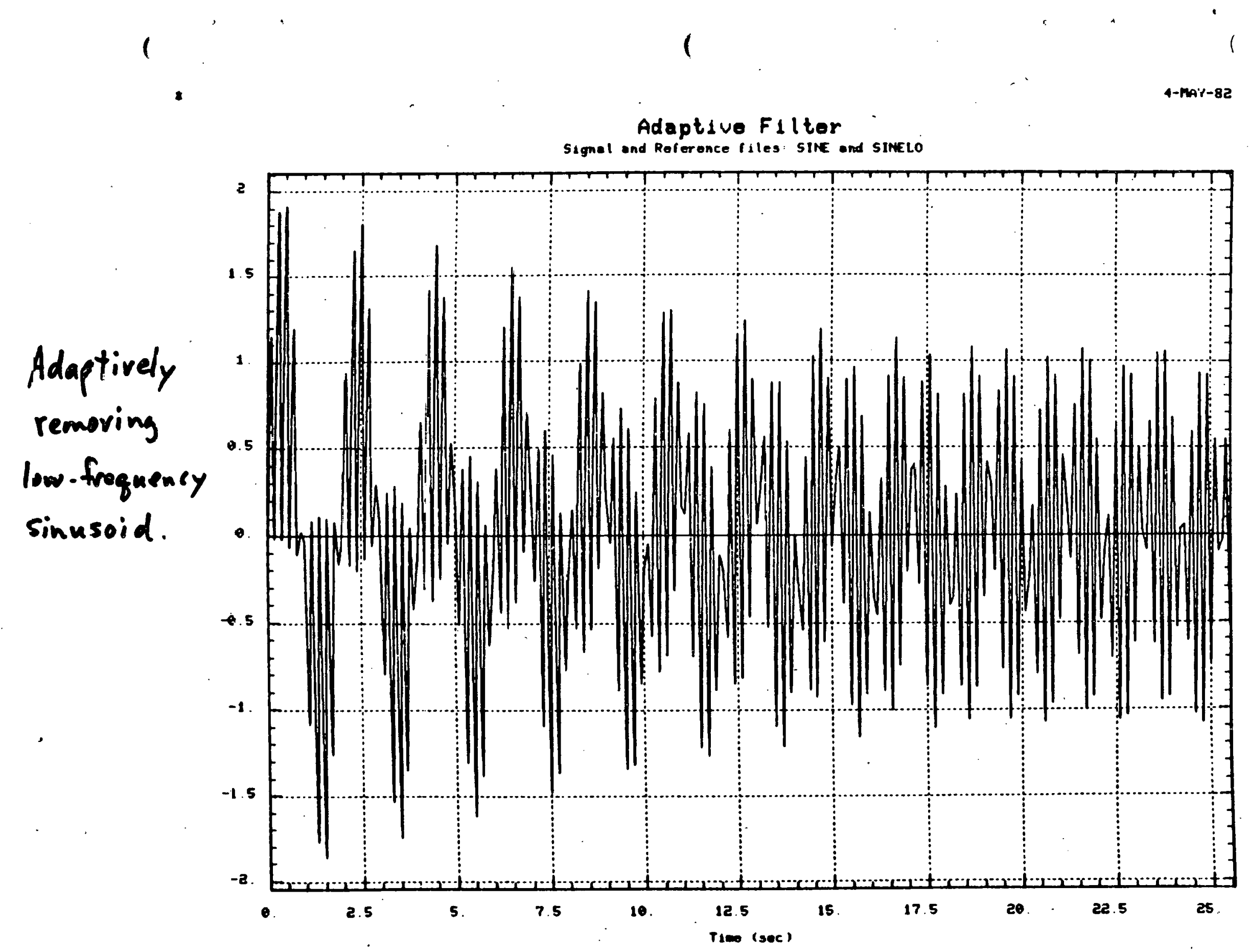


Ensemble Operations

(Option \#8 in main menu)

$\rightarrow$ Items 1 and 2 in meaner are the same as 1 and 2 in main means.

$\rightarrow$ Items 6 - (Pointwise addition) and 7 (Pin twine subtraction) are not covered but are obvious

54. 
Ensemble Operations

4-MAY-8z

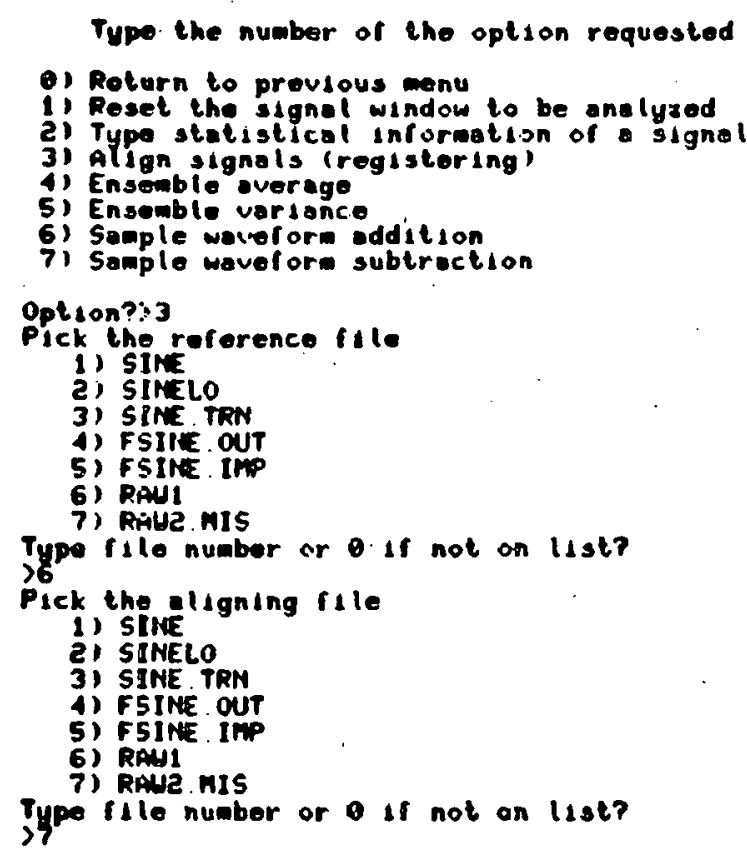

Operation \#

Align

$\rightarrow$ Reference is plotted first

55 


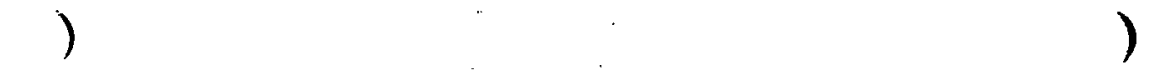

Q-Roturn. i-Horis . 2-Uart , 3-Poplot

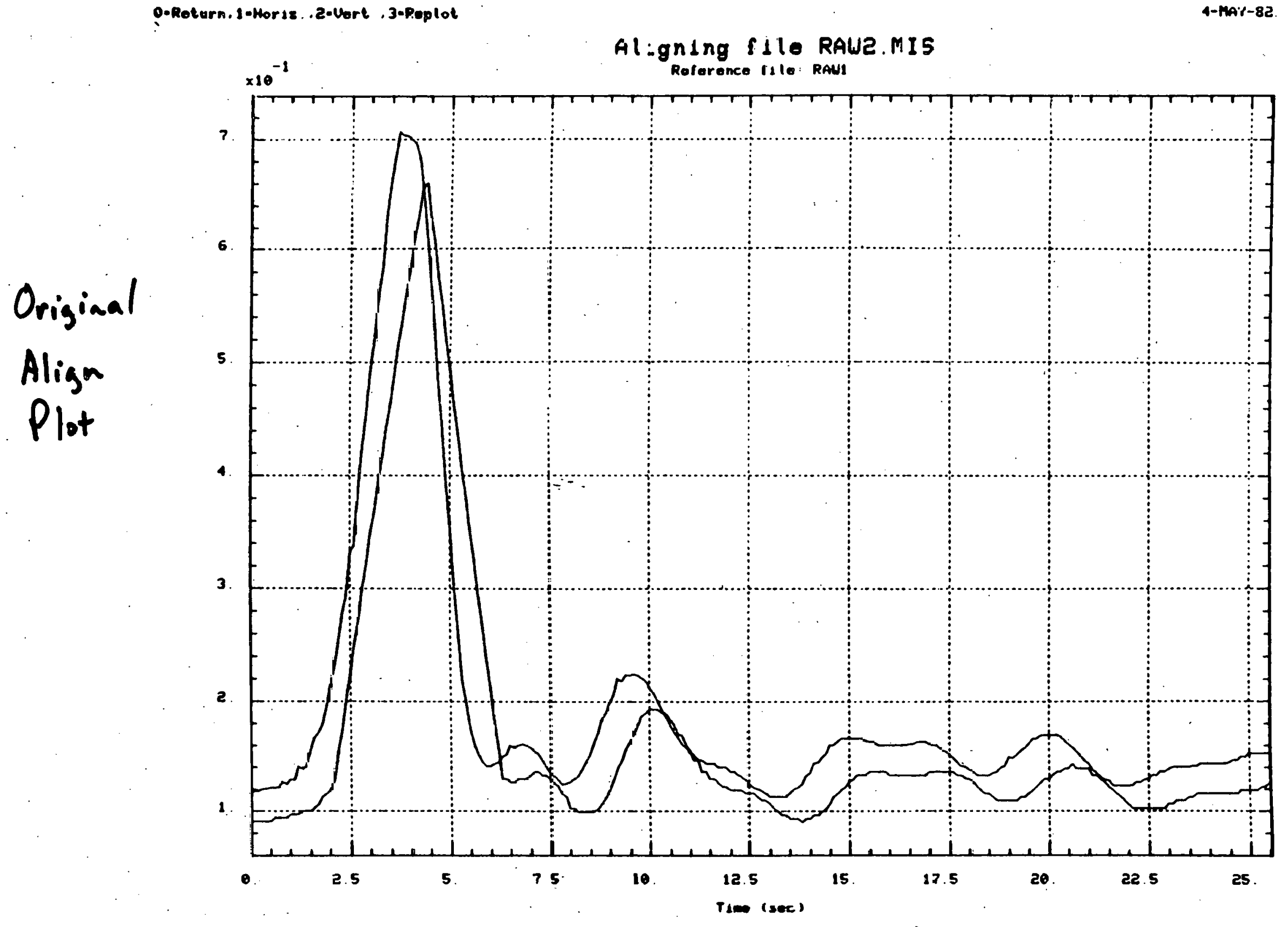




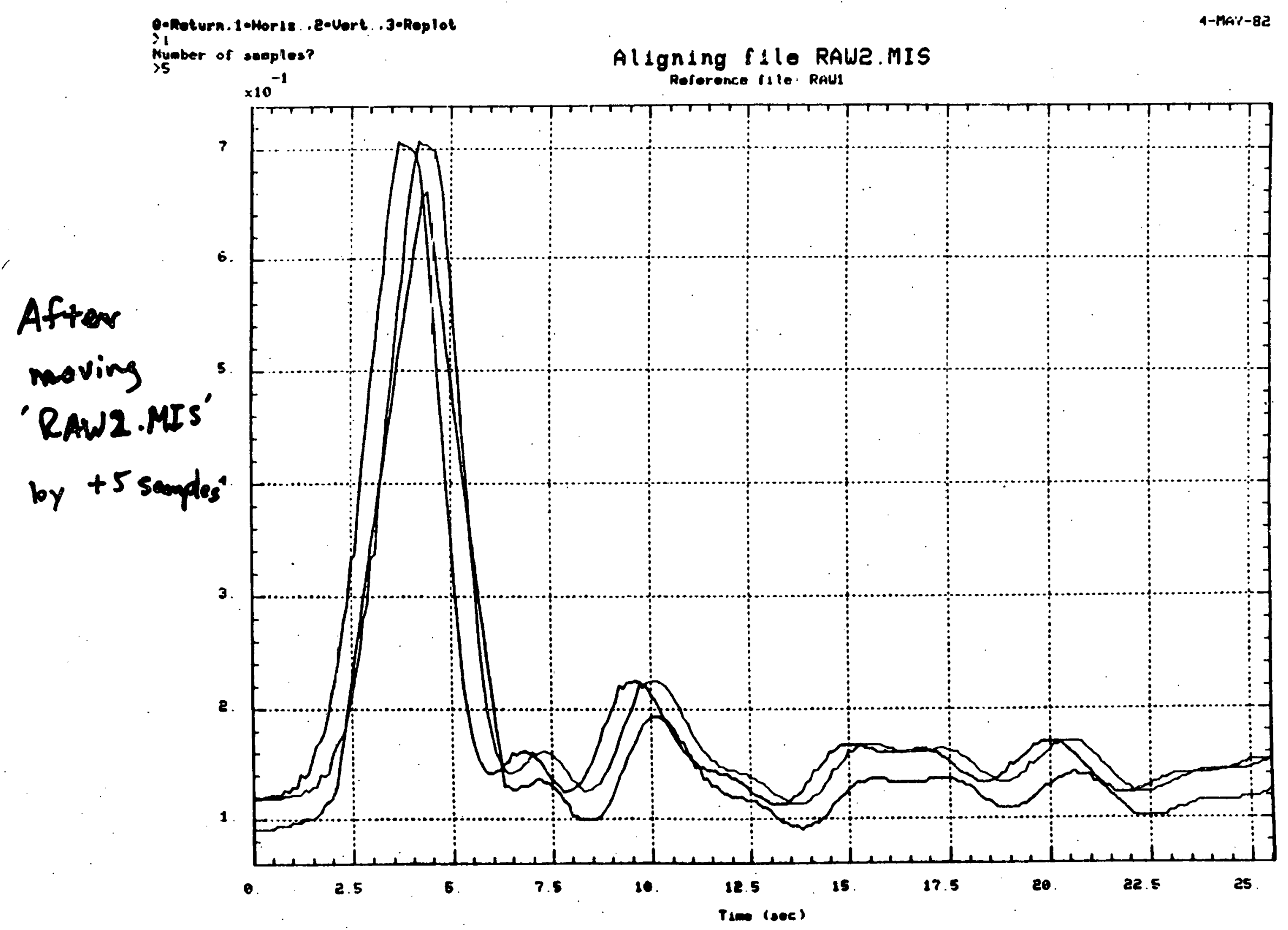


) ( )

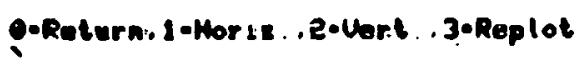

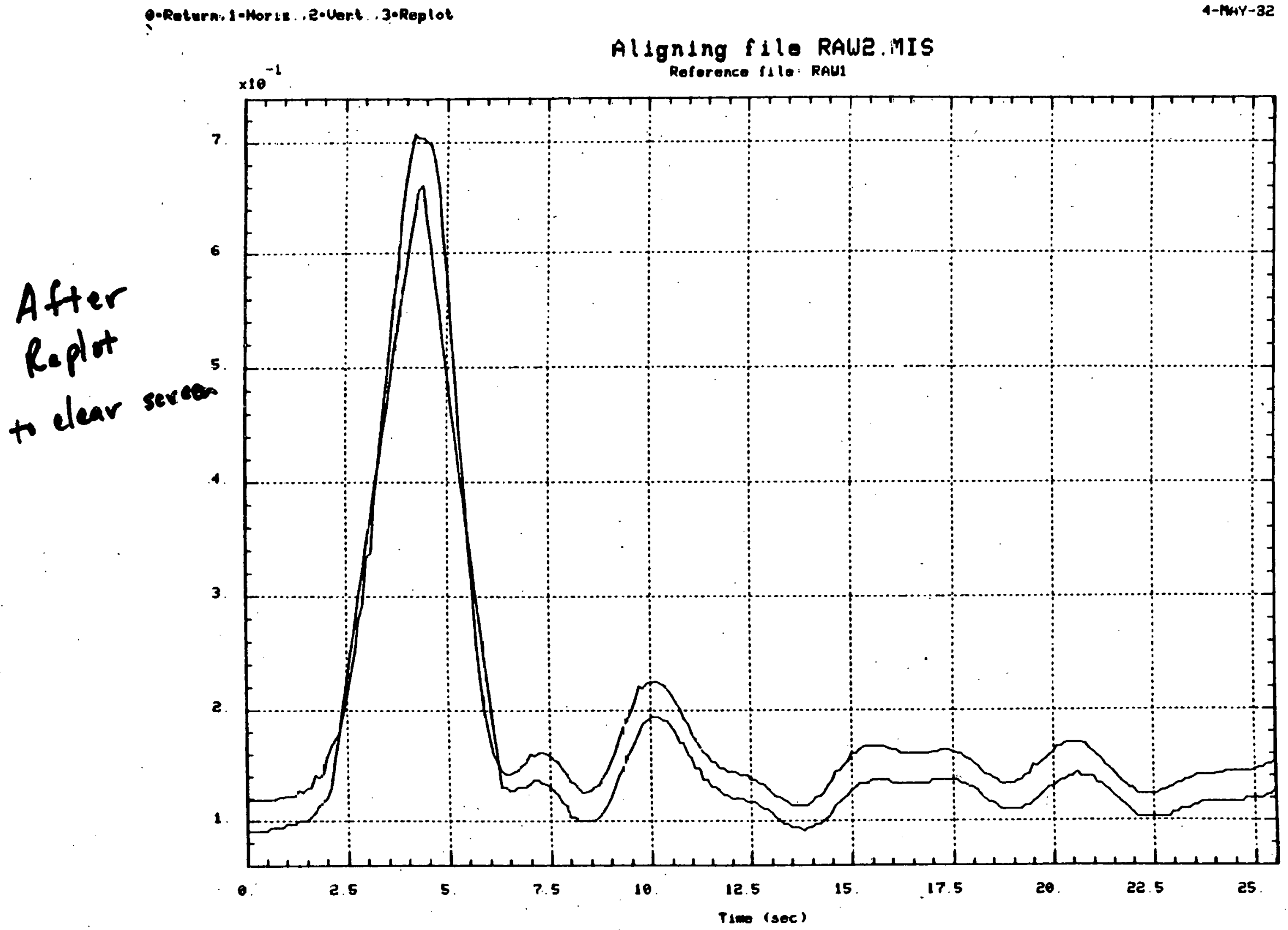




\section{PAGES 59 to 60 WERE INTENTIONALLY LEFT BLANK}


4-MAP-8Z

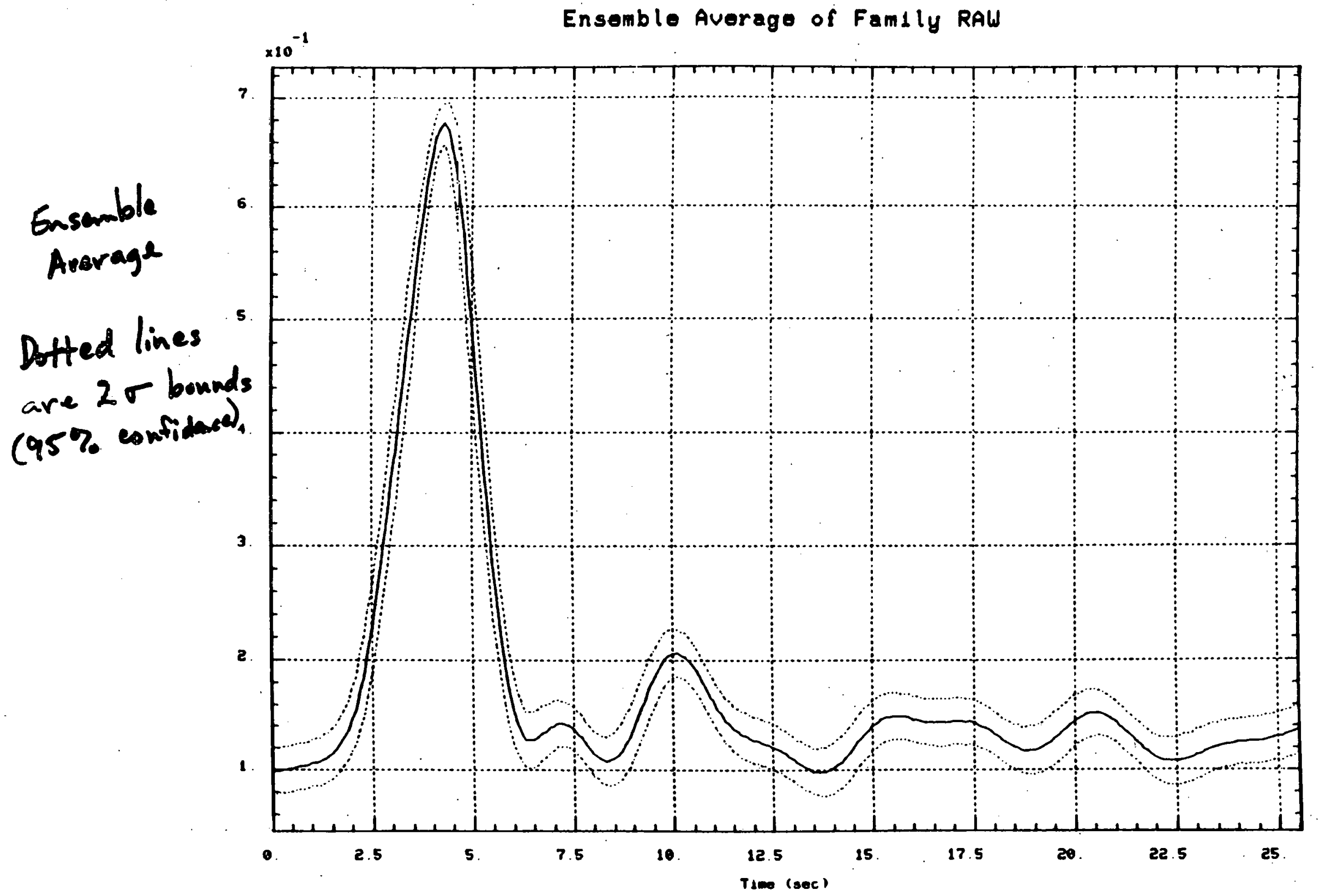

61 
Signal Analysis Program

$4-141 ;-32$

Type the number if the option requested

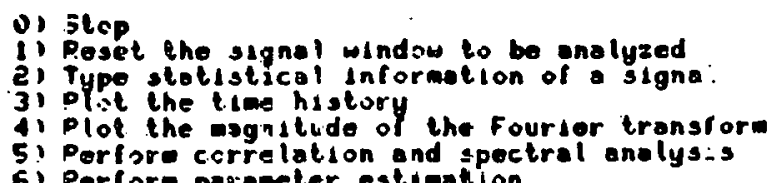

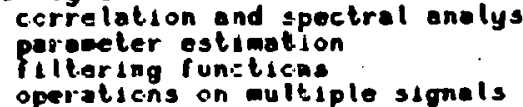

Option??

THE END

OR

"BEGINNING"

62 
$\frac{\text { ANALYZE DEMOS }}{\text { ON VAX } 11 / 780}$

- After logging on type:

SET DEFALLT SEPRG: [Class, DATA]

- Then to get the initial example type

(a) ANA1

and hit return's after each plot

- Then to get the data base for the entire dome, types

ANA DEMO

and try the functions we have presented.

HaPPY Analyzing!!!

65 


\section{DISCLAIMER}

This document was prepared as an account of work sponsored by an agency of the United States Government. Neither the United States Government nor the University of California nor any of their employees, makes any warranty, express or implied, or assumes any legal liability or responsibility for the accuracy, completeness, or usefulness of any information, apparatus, product, or process disclosed, or represents that its use would not infringe privately owned rights. Reference herein to any specific commercial products, process, or service by trade name, trademark, manufacturer, or otherwise, does not necessarily constitute or imply its endorsement, recommendation, or favoring by the United States Government or the University of California. The views and opinions of authors expressed herein do not necessarily state or reflect those of the United States Government thereof, and shall not be used for advertising or product endorsement purposes.

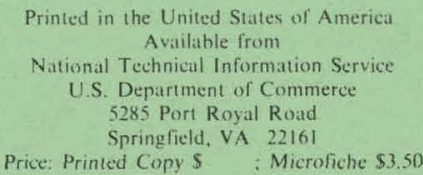

\begin{tabular}{|c|c|c|c|}
\hline Page Range & $\begin{array}{l}\text { Domestic } \\
\text { Price }\end{array}$ & Page Range & $\begin{array}{c}\text { Domestic } \\
\text { Price }\end{array}$ \\
\hline $001-025$ & $\$ 5.00$ & $326-350$ & $\$ 18.00$ \\
\hline $026-050$ & 6.00 & $351-375$ & 19.00 \\
\hline $051-075$ & 7.00 & $376-400$ & 20.00 \\
\hline $076-100$ & 8.00 & $401-425$ & 21.00 \\
\hline $101-125$ & 9.00 & $426-450$ & 22.00 \\
\hline $126-150$ & 10.00 & $451-475$ & 23.00 \\
\hline $151-175$ & 11.00 & $476-500$ & 24.00 \\
\hline $176-200$ & 12.00 & $501-525$ & 25.00 \\
\hline $201-225$ & 13.00 & $526-550$ & 26.00 \\
\hline $226-250$ & 14.00 & $551-525$ & 27.00 \\
\hline $251-275$ & 15.00 & $526-550$ & 28.00 \\
\hline $276-300$ & 16.00 & 601-up 1 & \\
\hline $301-325$ & 17.00 & & \\
\hline
\end{tabular}

1 Add 2.00 for each additional 25 page increment from 601 pages up. 


$$
1
$$

